\title{
Spatial association of the Cav1.2 calcium channel with
}

$\alpha_{5} \beta_{1}$-integrin

Juñ-Tzu Chao, Peichun Gui, Gerald W. Zamponi, George E. Davis and Michael J. Davis

Am J Physiol Cell Physiol 300:C477-C489, 2011. First published 22 December 2010; doi:10.1152/ajpcell.00171.2010

You might find this additional info useful...

Supplemental material for this article can be found at:

http://ajpcell.physiology.org/content/supp1/2011/03/03/ajpcell.00171.2010.DC1.html

This article cites 42 articles, 32 of which can be accessed free at:

http://ajpcell.physiology.org/content/300/3/C477.full.html\#ref-list-1

Updated information and services including high resolution figures, can be found at:

http://ajpcell.physiology.org/content/300/3/C477.full.html

Additional material and information about AJP - Cell Physiology can be found at:

http://www.the-aps.org/publications/ajpcell

This information is current as of March 23, 2012. 


\title{
Spatial association of the Cav1.2 calcium channel with $\alpha_{5} \beta_{1}$-integrin
}

\author{
Jun-Tzu Chao, ${ }^{1}$ Peichun Gui, ${ }^{1}$ Gerald W. Zamponi, ${ }^{\mathbf{2}}$ George E. Davis, ${ }^{\mathbf{1}}$ and Michael J. Davis ${ }^{1}$ \\ ${ }^{1}$ Department of Medical Pharmacology and Physiology, University of Missouri, Columbia, Missouri; and ${ }^{2}$ Department \\ of Physiology and Pharmacology, University of Calgary, Calgary, Alberta, Canada
}

Submitted 10 May 2010; accepted in final form 20 December 2010

Chao J, Gui P, Zamponi GW, Davis GE, Davis MJ. Spatial association of the Cav1.2 calcium channel with $\alpha_{5} \beta_{1}$-integrin. Am $J$ Physiol Cell Physiol 300: C477-C489, 2011. First published December 22, 2010; doi:10.1152/ajpcell.00171.2010.-Engagement of $\alpha_{5} \beta_{1}$-integrin by fibronectin (FN) acutely enhances Cav1.2 channel $\left(\mathrm{Ca}_{\mathrm{L}}\right)$ current in rat arteriolar smooth muscle and human embryonic kidney cells (HEK293-T) expressing $\mathrm{Ca}_{\mathrm{L}}$. Using coimmunoprecipitation strategies, we show that coassociation of $\mathrm{Ca}_{\mathrm{L}}$ with $\alpha_{5^{-}}$or $\beta_{1}$-integrin in HEK293-T cells is specific and depends on cell adhesion to FN. In rat arteriolar smooth muscle, coassociations between $\mathrm{Ca}_{\mathrm{L}}$ and $\alpha_{5} \beta_{1}$-integrin and between $\mathrm{Ca}_{\mathrm{L}}$ and phosphorylated c-Src are also revealed and enhanced by $\mathrm{FN}$ treatment. Using site-directed mutagenesis of $\mathrm{Ca}_{\mathrm{L}}$ heterologously expressed in HEK293-T cells, we identified two regions of $\mathrm{Ca}_{\mathrm{L}}$ required for these interactions: 1) $\mathrm{COOH}$-terminal residues $\mathrm{Ser}^{1901}$ and $\mathrm{Tyr}^{2122}$, known to be phosphorylated by protein kinase A (PKA) and c-Src, respectively; and 2) two proline-rich domains (PRDs) near the middle of the $\mathrm{COOH}$ terminus. Immunofluorescence confocal imaging revealed a moderate degree of wild-type $\mathrm{Ca}_{\mathrm{L}}$ colocalization with $\beta_{1}$-integrin on the plasma membrane. Collectively, our results strongly suggest that 1 ) upon ligation by $\mathrm{FN}, \mathrm{Ca}_{\mathrm{L}}$ associates with $\alpha_{5} \beta_{1}$-integrin in a macromolecular complex including PKA, c-Src, and potentially other protein kinases; 2) phosphorylation of $\mathrm{Ca}_{\mathrm{L}}$ at $\mathrm{Y}^{2122}$ and/or $\mathrm{S}^{1901}$ is required for association of $\mathrm{Ca}_{\mathrm{L}}$ with $\alpha_{5} \beta_{1}$-integrin; and 3) $\mathrm{c}$-Src, via binding to PRDs that reside in the II-III linker region and/or the $\mathrm{COOH}$ terminus of $\mathrm{Ca}_{\mathrm{L}}$, mediates current potentiation following $\alpha_{5} \beta_{1}$-integrin engagement. These findings provide new evidence for how interactions between $\alpha_{5} \beta_{1}$-integrin and FN can modulate $\mathrm{Ca}_{\mathrm{L}}$ entry and consequently alter the physiological function of multiple types of excitable cells.

focal adhesion complex; fibronectin; c-Src; proline-rich domain; protein kinase $\mathrm{A}$

INTEGRINS ARE HETERODIMERIC transmembrane proteins that facilitate adhesion and communication of cells with their surroundings through binding to extracellular matrix proteins (ECM). Extensive studies implicate an essential role for integrins in the transmission of mechanical forces at focal adhesion sites $(23,25,30)$. Integrin-mediated mechanotransduction is accomplished by activation of signaling molecules, such as focal adhesion kinase (FAK) and other tyrosine kinases, including c-Src, in conjunction with the recruitment of multiple proteins to focal adhesions and reorganization of the cytoskeleton (36). Integrins thereby translate physical forces into biochemical signals that ultimately alter cellular function.

$\mathrm{Ca}^{2+}$ entry through the L-type voltage-gated Cav1.2 calcium channel $\left(\mathrm{Ca}_{\mathrm{L}}\right)$ is required for stretch-induced contraction of vascular smooth muscle (VSM). Intracellular pressurization of isolated arterial myocytes leads to enhancement of $\mathrm{Ca}_{\mathrm{L}}$ current,

Address for reprint requests and other correspondence: M. J. Davis, Dept. of Medical Pharmacology and Physiology, M451 Med. Sci. Bldg., Univ. of Missouri, Columbia, 1 Hospital Dr., Columbia, MO 65211 (e-mail: davismj@health.missouri.edu). suggesting that $\mathrm{Ca}_{\mathrm{L}}$ may be modulated by mechanical stress applied to the plasma membrane (22). A link between $\mathrm{Ca}_{\mathrm{L}}$ and integrins in transducing mechanical force has also been demonstrated in arterioles. The application of peptides containing an Arg-Gly-Asp (RGD) sequence, a cryptic binding motif in ECM that becomes exposed during vascular injury (7), inhibits pressure-dependent myogenic tone, through interactions with multiple VSM and endothelial cell integrins (8). Moreover, function-blocking antibodies against $\alpha_{5^{-}}, \beta_{1^{-}}$, and $\beta_{3^{-}}$integrin significantly reduce the degree of myogenic constriction to pressure elevation (29). The effects of integrin antibodies on myogenic tone are mediated in part by altered $\mathrm{Ca}^{2+}$ entry through $\mathrm{Ca}_{\mathrm{L}}$ because electrophysiological studies reveal selective effects of integrin ligands on $\mathrm{Ca}_{\mathrm{L}}$ current; the engagement and clustering of $\alpha_{5} \beta_{1}$-integrin by insoluble fibronectin (FN) or anti- $\alpha_{5}$-integrin antibody acutely potentiates $\mathrm{Ca}_{\mathrm{L}}$ current, whereas engagement of $\alpha_{\mathrm{v}} \beta_{3}$-integrin by vitronectin or soluble ligands inhibits $\mathrm{Ca}_{\mathrm{L}}$ current in isolated VSM cells (41). Using site-directed mutagenesis strategies, two phosphorylation sites within the $\mathrm{COOH}$ terminus of the $\alpha_{1 \mathrm{C}^{-}}$subunit of $\mathrm{Ca}_{\mathrm{L}}\left(\alpha_{1 \mathrm{C}^{-}}\right.$ $\mathrm{Ca}_{\mathrm{L}}$ ) were identified as targets of protein kinase A (PKA) and c-Src that become activated downstream from $\alpha_{5} \beta_{1}$-integrin ligation (14).

A critical remaining issue is the extent to which $\alpha_{5} \beta_{1}$ integrin, PKA, c-Src, and $\mathrm{Ca}_{\mathrm{L}}$ are spatially coupled within a cell. In the present study, we tested the hypothesis that $\alpha_{5} \beta_{1}$ integrins spatially associate with $\mathrm{Ca}_{\mathrm{L}}$ and that this association is required to modulate $\mathrm{Ca}_{\mathrm{L}}$ function. Using human embryonic kidney cells (HEK293-T) overexpressing the neuronal isoform of $\mathrm{Ca}_{\mathrm{L}}$ and VSM cells from rat skeletal muscle arterioles as model systems, the interactions between endogenous $\alpha_{5} \beta_{1}$ integrin and $\mathrm{Ca}_{\mathrm{L}}$ and between $\mathrm{c}-\mathrm{Src}$ and $\mathrm{Ca}_{\mathrm{L}}$ were examined using immunoprecipitation (IP), immunoblotting (IB), immunofluorescence confocal microscopy, and patch-clamp methods.

\section{METHODS}

Cell culture and transient transfection. HEK293-T/(TSA201) cells were maintained in 10\% FBS (Hyclone)-DMEM (high glucose) supplemented with $2 \mathrm{mM}$ glutamine, 100 units of penicillin, and $100 \mu \mathrm{g}$ of streptomycin in $5 \% \mathrm{CO}_{2}$ at $37^{\circ} \mathrm{C}$. When cells reached $70-80 \%$ confluence, wild-type (WT) or mutant neuronal Cav1.2 calcium channel $\left(\mathrm{Ca}_{\mathrm{L}}\right)$ cDNAs composed of $\alpha_{1 \mathrm{C}-\mathrm{c}}(6 \mu \mathrm{g}), \beta_{1 \mathrm{~b}}(3 \mu \mathrm{g})$, and $\alpha_{2} \delta$ (2 $\mu \mathrm{g})$ subunits, in a total volume of $14 \mu \mathrm{l}$, were transfected into HEK293-T cells grown in 60-mm tissue culture dishes containing 2.5 $\mathrm{ml}$ of DMEM with Lipofectamine $2000(20 \mu \mathrm{l})$ for 18-24 h. Green fluorescent protein (GFP; $0.5-1 \mu \mathrm{g}$ ) was cotransfected with $\mathrm{Ca}_{\mathrm{L}}$ to monitor transfection efficiency. Untransfected cells were used as a control. Cells were incubated for another $24 \mathrm{~h}$ posttransfection before passing and plating onto either FN (catalog no. 354403, BD BioCoat, BD Biosciences), BSA (2\%), or poly-L-lysine-treated plates for $1 \mathrm{~h}$, followed by protein isolation or immunofluorescence imaging. To account for variation in the expression level of $\alpha_{1 C}-\mathrm{Ca}_{\mathrm{L}}$ due to 
variation in transfection efficiency among the different $\mathrm{Ca}_{\mathrm{L}}$ mutants, the experiments for all $\mathrm{Ca}_{\mathrm{L}}$ mutants were performed in parallel with WT-Ca $a_{L}$ transfection using the same passage of cells.

For electrophysiological experiments, HEK293-T cells were transfected using calcium phosphate, after which patch-clamp recordings were performed $48-72 \mathrm{~h}$ posttransfection as previously described (14). Only single cells expressing GFP were used for electrophysiological protocols.

The various mutations in the $\alpha_{1 \mathrm{C}}-\mathrm{COOH}$ terminus were generated using site-directed mutagenesis as described previously (14) and as illustrated in Fig. 1.

Isolation of skeletal muscle arterioles. The isolation of first- and second-order arterioles from rat cremaster muscle was performed as described previously $(21,40,41)$, except for addition of $1 \times$ Halt Protease and Phosphatase Inhibitor Cocktail (Thermo Scientific) into the dissection chamber immediately before dissection. All animal protocols were approved by the University of Missouri Animal Care and Use Committee and conformed to the Public Health Service Policy for the Humane Care and Use of Laboratory Animals (PHS Policy, 1996).

Electrophysiological recording. Patch-clamp recordings were made using an EPC9 amplifier under the control of Pulse software (HEKA Instruments) in the conventional whole cell mode, as previously described (14). Pipettes were filled with $\mathrm{Cs}^{+}$pipette solution containing (in mM) $110 \mathrm{CsCl}, 20$ TEA chloride, 10 EGTA, $2 \mathrm{MgCl}_{2}$, 10 HEPES, and $1 \mathrm{CaCl}_{2}(\mathrm{pH} 7.2$ with $\mathrm{CsOH}) . \mathrm{Ba}^{2+}$ was used as the charge carrier to increase the magnitude of the inward current and to minimize calcium-dependent current inactivation. $\mathrm{Cs}^{+}$was used to block endogenous $\mathrm{K}^{+}$current.

Immunoprecipitation and immunoblotting. Proteins from HEK293-T cells were isolated as described by Ling et al. (27) with minor modifications. The lysis buffer was composed of $1 \%$ Triton X-100 containing the following: $2.5 \mathrm{mM}$ Tris, $\mathrm{pH} 7.4,13.8 \mathrm{mM} \mathrm{NaCl}, 0.3$ $\mathrm{mM} \mathrm{KCl}, 2 \mathrm{mM}$ EDTA, $1 \mathrm{mM}$ EGTA, $10 \mathrm{mM} \mathrm{NaF}, 1 \mathrm{mM}$ benzamidine, $1 \mathrm{mM} \mathrm{Na} \mathrm{VO}_{4}, 4 \mathrm{mM}$ Pefabloc, $10 \mu \mathrm{g} / \mathrm{ml}$ leupeptin, $10 \mu \mathrm{g} / \mathrm{ml}$ aprotinin, $10 \mu \mathrm{g} / \mathrm{ml}$ of calpain I and II, and $10 \mu \mathrm{g} / \mathrm{ml}$ pepstatin A. Isolation of total proteins in arterioles was performed as described above except for using $0.25 \%$ Triton X-100, along with $2 \%$-octyl$\beta$-D-glucopyranoside to lyse arterioles. Arterioles (1st order and 2nd order) were snap-frozen in liquid nitrogen after dissection. Vessels were cut into smaller pieces and pulverized with a plastic pestle in $0.65-\mathrm{ml}$ centrifuge tubes in the presence of an optimal amount of lysis buffer. Tubes containing arterioles were frequently dipped into liquid nitrogen and kept on dry ice during pulverization. Three hundred to four hundred micrograms of total protein (150-250 $\mu \mathrm{g}$ for arterioles) were precleared with protein A/G agarose beads (catalog no. SC2003; Santa Cruz) in the presence of either rabbit or mouse $\operatorname{IgG}$

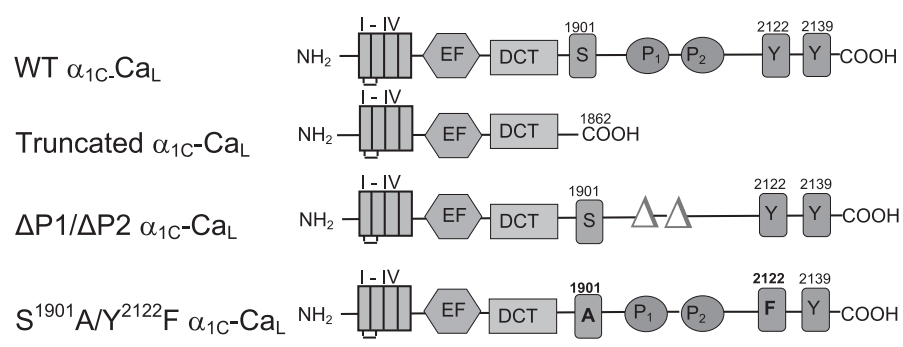

Fig. 1. Schematic depicting the domain structure of wild-type (WT) L-type voltage-gated Cav1.2 calcium channel $\left(\mathrm{Ca}_{\mathrm{L}}\right) \alpha_{1 \mathrm{C}}$-subunit and mutant $\alpha_{1 \mathrm{C}}-\mathrm{Ca}_{\mathrm{L}}$ constructs used in this study. $I-I V$, the four transmembrane repeat of $\alpha_{1 \mathrm{C}}$. EF and DCT, EF hand motif and the distal $\mathrm{COOH}$ terminus inhibitory domain; $\mathrm{P}$, proline-rich domain; truncated $\alpha_{1 \mathrm{C}}-\mathrm{Ca}_{\mathrm{L}}$, WT $\alpha_{1 \mathrm{C}}-\mathrm{Ca}_{\mathrm{L}}$ missing the distal $\mathrm{COOH}$-terminal 280 amino acids; $\Delta \mathrm{P} 1 / \Delta \mathrm{P} 2 \alpha_{1 \mathrm{C}}-\mathrm{Ca}_{\mathrm{L}}$, WT $\alpha_{1 \mathrm{C}}-\mathrm{Ca}$ missing the two proline-rich domains (aa 1955-1959; aa 1967-1973); $\mathrm{S}^{1901} \mathrm{~A} / \mathrm{Y}^{2122} \mathrm{~F}$ $\alpha_{1 \mathrm{C}}-\mathrm{Ca}_{\mathrm{L}}$, two single-point mutations at serine $\left(\mathrm{S}^{1901} \mathrm{~A}\right)$ and tyrosine $\left(\mathrm{Y}^{2122} \mathrm{~F}\right)$ in full-length neuronal WT-Ca $a_{L}$. (catalog no. PP64 and PP54, respectively; Millipore), followed by overnight IP in lysis buffer at $4^{\circ} \mathrm{C}$ with one of the following antibodies: 1) either rabbit anti-Cav1.2 polyclonal antibody (Ab) $(3.2 \mu \mathrm{g}$; catalog no. AB5156, Millipore) or pan Calcium Channel Ab (catalog no. Ab6298, Abcam), recognizing the $\alpha_{1 C^{-}}$subunit of $\mathrm{Ca}_{L}\left(\alpha_{1 \mathrm{C}}-\mathrm{Ca}_{\mathrm{L}}\right)$; 2) mouse anti-human $\beta_{1}$-integrin monoclonal $\mathrm{Ab}(5 \mu \mathrm{g}$, clone B3B11, catalog no. MAB2251Z, Millipore); 3) purified mouse anti-human $\alpha_{5}$-integrin $\mathrm{Ab}(5 \mu \mathrm{g}$, clone $1 / \mathrm{CD} 49 \mathrm{e}$, catalog no. 610634, BD Biosciences); 4) mouse anti-pp60c-Src (4 $\mu$ g, clone GD11, catalog no. 05-184, Millipore); or 5) anti-phosphorylated-Tyr Ab (5 $\mu \mathrm{g}$, clone 4G10, catalog no. 05-321, Millipore). The immune complex was captured using either protein A (catalog no. SC-2001, Santa Cruz) or protein $\mathrm{G}$ agarose beads (catalog no. 17088601, Amersham) prior to SDS-PAGE $(6 \%)$, followed by overnight transfer to nitrocellulose membrane $(0.45 \mathrm{~nm})$ and IB. To confirm binding specificity, the whole cell lysate was also immunoprecipitated with 1 ) control IgG for the appropriate host species and captured by protein A or protein $G$ beads, or 2) protein A or protein $\mathrm{G}$ beads alone. Equal loading of total protein was confirmed by Ponceau staining (Sigma) before IB. $\mathrm{Ca}_{\mathrm{L}}$ was detected using rabbit anti-Ca $a_{L} \alpha_{1 C}$-subunit $\mathrm{Ab}$ (catalog no. AB5156, 1:6,500 dilution) for HEK293-T cells or pan Calcium Channel $\mathrm{Ab}\left(1: 2,500\right.$ dilution) for rat arterioles. Endogenous $\beta_{1^{-}}$ integrin was detected using mouse anti-human $\beta_{1}$-integrin $A b$ or rabbit anti-rat $\beta_{1}$-integrin $\mathrm{Ab}$ (catalog no. MAB2251Z, 1:1,400 dilution and catalog no. AB1952P, 1:1,500 dilution, respectively; Millipore). c-Src or phosphorylated c-Src was detected using anti-pp60c-Src (catalog no. 05-184, 1:1,200 dilution, Millipore) or rabbit anti-rat phospho-Src family (Tyr416) Ab (catalog no. 2101S, 1:1,000 dilution, Cell Signaling Technology), respectively. The immune complexes were incubated with either goat anti-rabbit IgG-horseradish peroxidase (HRP)-conjugated antibody (H\&L, 1:120,000 dilution, catalog no. AP132P, Millipore) or donkey anti-mouse-IgG-HRP-conjugated antibodies (H\&L, 1:60,000 dilution, catalog no. 715-035-150, Jackson Research Laboratory) followed by detection with Pierce SuperSignal extended Dura or Femto substrate (Thermo Scientific). After probing, the blot was stripped with Restore Western blot stripping buffer (Thermo Scientific) and reprobed with either anti- $\alpha_{1 C}-\mathrm{Ca}_{L}$, anti- $\beta_{1^{-}}$ integrin, or anti-c-Src Ab to assess the relative loading. For detection of the immune complex from arterioles, the blot was processed as described above except that SuperSignal Western Blot Enhancer (catalog no. 46641, Thermo Scientific) was used according to the manufacturer's instruction before IB. The results were captured by exposure to Kodak Biomax MR, MS, or Light film (Sigma), and the band intensity for the protein of interest was quantified using Bio-Rad Quantity One. Quantification of co-IP was determined as described by Cherubini et al. (4). The ratio of immunoprecipitated $\alpha_{1 C}-\mathrm{Ca}_{L}$ to $\beta_{1}$-integrin in WT- $\alpha_{1 C^{-}}-\mathrm{Ca}_{\mathrm{L}}$-expressing cells was set as 1 . The ratio of immunoprecipitated $\alpha_{1 C}-\mathrm{Ca}_{\mathrm{L}}$ to $\beta_{1}$-integrin in mutant $\alpha_{1 \mathrm{C}}-\mathrm{Ca}_{\mathrm{L}}$-expressing cells was expressed relative to WT- $\alpha_{1 \mathrm{C}}-\mathrm{Ca}_{\mathrm{L}}$.

Immunofluorescence confocal imaging. To determine the distribution and expression of $\alpha_{1 C}-\mathrm{Ca}_{\mathrm{L}}$ and $\beta_{1}$-integrin, cells were plated on poly-L-lysine or FN-coated tissue culture dishes with coverglass bottoms (Fluorodish, catalog no. FD35-100, WPI) for $1 \mathrm{~h}$ after $24 \mathrm{~h}$ of transfection, followed by fixation with $2 \%$ paraformaldehyde and staining as described previously (40). $\alpha_{1 C^{-}} \mathrm{Ca}_{\mathrm{L}}$ was determined using the same antibody for IP, followed by donkey anti-rabbit IgG conjugated to Alexa 488 (1:1,600 dilution, catalog no. A21206, Invitrogen). $\beta_{1}$-Integrin was detected using mouse anti-human $\beta_{1}$-integrin $\mathrm{Ab}$ (1:75 dilution, clone HUTS 21, catalog no. 556037, BD Biosciences), followed by goat anti-mouse IgG conjugated with Alexa 555 (1:1,400 dilution, catalog no. A21424, Invitrogen). Counterstaining of nuclei was performed using TO-PRO-3 $(0.5 \mu \mathrm{M}$, catalog no. T3605, Invitrogen). Staining of paxillin or vinculin was determined using rabbit anti-paxillin polyclonal $\mathrm{Ab}$ (1:300 dilution, catalog no. AB3794, Millipore) or mouse anti-vinculin antibody (clone V284, 1:80 dilution; catalog no. 05-386, Millipore). Cells were incubated with donkey anti-rabbit IgG conjugated with Alexa 488 alone or goat anti-mouse 
IgG conjugated to Alexa 555 alone, or the combination of both as a negative control to confirm the specificity of staining. ProLong Gold Antifade Reagent (catalog no. P36934, Invitrogen) was applied to the sample after staining, followed by storage at $-30^{\circ} \mathrm{C}$ until images were captured.

Immunofluorescence images were taken using a laser-scanning confocal system (Leica TCS SP5 Microsystems) attached to an upright microscope (Leica DM $6000 \mathrm{CS}$ ) and were collected using a $\times 63$ oil objective (numerical aperture 1.42). Excitation of the fluorophores was achieved using argon 488, He/Ne 543, or He/Ne $633 \mathrm{~nm}$ laser combinations with pinhole size set at 1 airy disk. Images were taken at $512 \times 512$ pixels with a step size of $0.2 \mu \mathrm{m}$ and a zoom factor of 5 . The image size was $\sim 49.2 \mu \mathrm{m}^{2}$.

To prevent bleed-through of different wavelengths that might interfere with colocalization analysis, all the images were taken using a sequential acquisition procedure at wavelengths of $488 / 519 \mathrm{~nm}$ (excitation/emission) for the $\alpha_{1 C}-\mathrm{Ca}_{\mathrm{L}}$-subunit; 543/569 $\mathrm{nm}$ (excitation/emission) for $\beta_{1}$-integrin, and $633 / 656 \mathrm{~nm}$ (excitation/emission) for nuclear staining.

Quantification of $\alpha_{1 C^{-}} C a_{L}$ association with $\beta_{1}$-integrin. The association of $\alpha_{1 C}-C_{L}$ with $\beta_{1}$-integrin was analyzed with ImageJ software (version 1.39d, National Institutes of Health, Bethesda, MD). The degree of $\alpha_{1 C}-C_{L}$ association with $\beta_{1}$-integrin was quantified using Pearson's coefficient, Mander's coefficient, and intensity correlation analysis (ICA) $(24,33)$. The advantage of using ICA analysis is that it avoids taking the overlap of randomly distributed proteins into account for colocalization if the intensity of the two target proteins does not vary coincidently (24). ICA values are distributed between -0.5 and +0.5 . ICA values close to 0 indicate random staining, values $-0.5 \leq \mathrm{ICA}<0$ represent segregated staining, and values $0<\mathrm{ICA} \leq+0.5$ represent interdependent staining. The degree of $\alpha_{1 C}-\mathrm{Ca}_{\mathrm{L}}$ association with $\beta_{1}$-integrin was normalized to the average ICA value for the coassociation of paxillin with vinculin (0.25), which was shown previously to be very strong (37).

Statistical analysis. Results are presented as means \pm SE from at least three independent experiments for IP or four independent experiments for immunofluorescence confocal imaging (IF). Statistical differences were analyzed using GraphPad InStat or Prism (version 3.06 and version 5.0, respectively; GraphPad, San Diego, CA) with either analysis of variance or unpaired $t$-tests. $P<0.05$ was considered significant.

\section{RESULTS}

$C a_{L}$ association with $\alpha_{5} \beta_{1}$-integrin depends on adhesion to fibronectin. To determine whether $\alpha_{1 C}-\mathrm{Ca}_{\mathrm{L}}$ associated with $\alpha_{5} \beta_{1}$-integrin, IP of whole cell lysates from HEK293-T cells expressing the neuronal $\mathrm{Ca}_{\mathrm{L}}$ using either anti- $\beta_{1^{-}}$or anti- $\alpha_{5^{-}}$ integrin antibody was followed by IB to probe for the presence of $\alpha_{1 C}-\mathrm{Ca}_{\mathrm{L}}$. The neuronal $\mathrm{Ca}_{\mathrm{L}}$ isoform was used as a model system because $\alpha_{1 C}-\mathrm{Ca}_{\mathrm{L}}$ mutants had been previously generated by site-directed mutagenesis strategies; neuronal and smooth muscle (SM) cell (SMC) $\mathrm{Ca}_{\mathrm{L}}$ isoform share $90 \%$ homology in amino acid sequence, and we previously demonstrated that heterologously expressed rat neuronal and SMC isoforms (Cav1.2c and Cav1.2b, respectively) showed a similar degree of current potentiation following $\alpha_{5} \beta_{1}$-integrin ligation (14). We first determined the association between $\alpha_{1 C^{-}-a_{L}}$ and $\beta_{1}$-integrin in cells plated on poly-L-lysine-treated dishes. As shown in Fig. $2 A$, no appreciable $\alpha_{1 C}-C_{2}$ was observed after IP using anti- $\beta_{1}$-integrin $\mathrm{Ab}$ in either control (untransfected cells, lane 2) or cells expressing WT $\alpha_{1 \mathrm{C}}-\mathrm{Ca}_{\mathrm{L}}$ (lane 7) when plated on poly-L-lysine-treated dishes. However, when cells expressing WT $\alpha_{1 \mathrm{C}}-\mathrm{Ca}_{\mathrm{L}}$ were plated on FN (Fig. $2 B$ ), $\alpha_{1 \mathrm{C}}-\mathrm{Ca}_{\mathrm{L}}$ was detected after IP of the lysate using either anti- $\alpha_{5^{-}}$(lane 4 ) or anti- $\beta_{1}$-integrin antibody (lane 3 ). No specific $\alpha_{1 C}-\mathrm{Ca}_{\mathrm{L}}$ band was observed in cells expressing $\alpha_{1 \mathrm{C}}-\mathrm{Ca}_{\mathrm{L}}$ plated on BSAcoated dishes after IP using anti- $\beta_{1}$-integrin or anti-c-Src Ab (Supplemental Fig. S1A, lanes 6 and 7, respectively) or after IP of the lysate using mouse IgG or protein-G (Fig. $2 B$, lanes 2 , 5 , and 9). These results indicate that the association of $\alpha_{1 C}-C_{L}$ with $\alpha_{5}$ or $\beta_{1}$-integrin in HEK293-T cells is specific and depends on cell adhesion to FN.

To confirm that the effect of $\mathrm{FN}$ on $\alpha_{1 C^{-}} \mathrm{Ca}_{\mathrm{L}}$ association with $\beta_{1}$-integrin was not an artifact of $\mathrm{Ca}_{\mathrm{L}}$ overexpression in HEK293-T cells, we examined the same interaction in lysates from arteriolar SM. Arterioles were dissected and then incubated with exogenous FN abluminally $(300 \mu \mathrm{g} / \mathrm{ml})$ for $1 \mathrm{~h}$. When arteriolar SM lysates were immunoprecipitated with

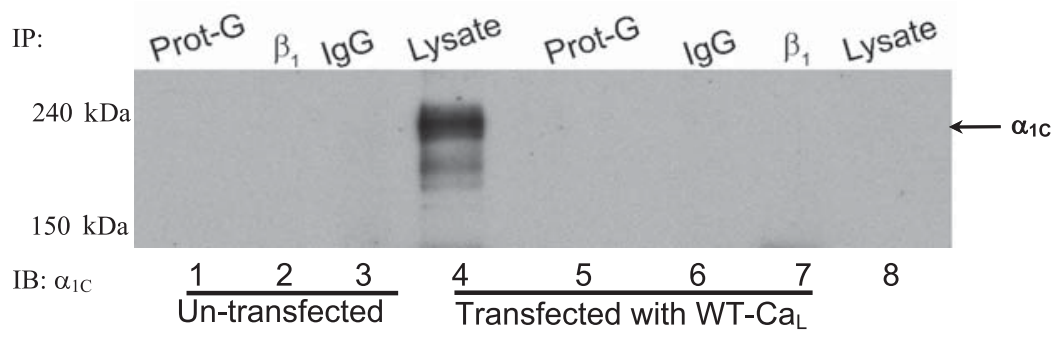

\section{B HEK293-T cells plated on fibronectin}

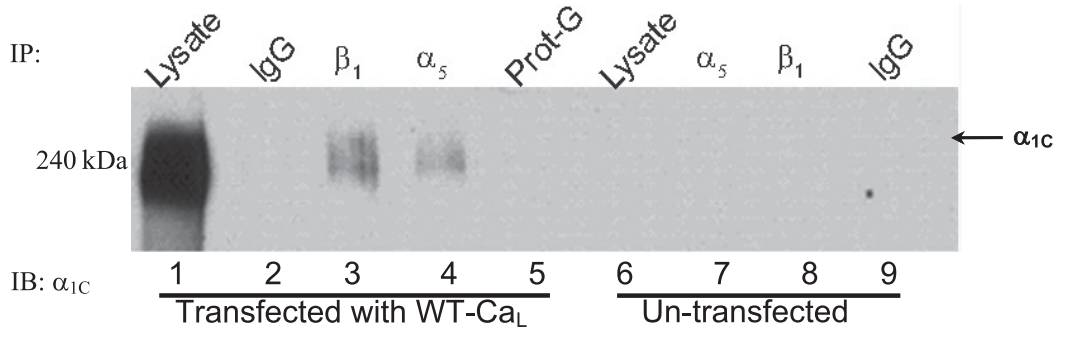

Fig. 2. $\mathrm{Ca}_{\mathrm{L}}$ association with $\alpha_{5^{-}}$or $\beta_{1}$-integrin depends on adhesion of human embryonic kidney cells (HEK293-T) to fibronectin (FN). A: representative blot showing coimmunoprecipitation (co-IP) protocol on protein lysed from control (untransfected) or neuronal WT-Ca $\mathrm{L}_{\mathrm{L}}$-expressing HEK293-T cells plated onto poly-L-lysine-treated dishes. No $\alpha_{1 C^{-}} \mathrm{Ca}_{\mathrm{L}}$ appears to be pulled down by IP with anti- $\beta_{1}$-integrin antibody $(\mathrm{Ab})$ in either control (untransfected) or WT $\mathrm{Ca}_{\mathrm{L}}$-expressing cells (lanes 2 and 7, respectively). Expression of $\alpha_{1 \mathrm{C}}-\mathrm{Ca}_{\mathrm{L}}$ was confirmed in cells expressing WT-CaL by immunoblotting (IB) with anti- $\alpha_{1 C^{-}}-\mathrm{Ca}_{\mathrm{L}} \mathrm{Ab}$, showing a specific band at molecular mass 190 to $240 \mathrm{kDa}$ (lane 4). B: representative blot showing pull-down of $\alpha_{1 C}$ by anti- $\alpha_{5}$ or anti- $\beta_{1}$-integrin $A b$ (lanes 4 and 3, respectively) only from cells expressing WT$\mathrm{Ca}_{\mathrm{L}}$, not control (untransfected) cells (lanes 7 and 8 , respectively), when plated onto FN-coated plates before IP and IB. All blots were repeated at least three times. Prot-G, protein-G. 
anti- $\alpha_{1 C}-\mathrm{Ca}_{\mathrm{L}}, \beta_{1}$-integrin was detected only in arterioles incubated with FN (Fig. 3A, lanes 1 and 2), compared with control (lanes 5 and 6 ). The same blot was also stripped and reprobed for the expression of $\alpha_{1 C}-\mathrm{Ca}_{\mathrm{L}}$. In addition, incubation with FN did not substantially change the level of $\alpha_{1 \mathrm{C}}-\mathrm{Ca}_{\mathrm{L}}$ expression in arterioles (Supplemental Fig. S1B). These results indicate that the association of $\alpha_{1 C^{-}}-a_{L}$ with $\beta_{1}$-integrin in SMC depends on ligation of $\beta_{1}$-integrin by FN.

c-Src, a tyrosine kinase activated upon integrin ligation by ECM ligands (18), has been shown to modulate $\mathrm{Ca}_{\mathrm{L}}$ function in SMC $(2,3,19,39)$. Thus, we also examined whether c-Src associated with $\alpha_{1 \mathrm{C}}-\mathrm{Ca}_{\mathrm{L}}$ in arteriolar SM and whether FN was important for this association. As shown in Fig. 3B, c-Src was detected in immunoprecipitates using two different anti- $\alpha_{1 C^{-}}$ $\mathrm{Ca}_{\mathrm{L}}$ antibodies (Fig. 3B, lanes 1 and 2). However, abluminal incubation with FN did not substantially change the degree of c-Src association with $\alpha_{1 \mathrm{C}-} \mathrm{Ca}_{\mathrm{L}}$ (Fig. $3 B$, lanes 1 and 2 vs. lanes 5 and 6 ). Next, we tested whether incubation with FN altered the phosphorylation status of c-Src in association with $\alpha_{1 \mathrm{C}}-\mathrm{Ca}_{\mathrm{L}}$. A basal level of phosphorylated c-Src was observed in untreated control lysate (Fig. 3C, lane 3) and in lysate from arteriolar SM incubated with FN (lane 4). In contrast to Fig. $3 B$, phosphorylated c-Src coassociated with $\alpha_{1 \mathrm{C}}-\mathrm{Ca}_{\mathrm{L}}$ only in arteriolar SM incubated with FN, not in control arteriolar SM (Fig. 3C, lanes 1 and 2 vs. lanes 5 and 6 , respectively). These results suggest that the association of $\alpha_{1 \mathrm{C}}-\mathrm{Ca}_{\mathrm{L}}$ with $\mathrm{c}-\mathrm{Src}$ in arteriolar SM is independent of FN, whereas the association of $\alpha_{1 C}-C_{L}$ with phosphorylated c-Src depends on integrin engagement by FN.

The COOH terminus of $\alpha_{1 C^{-}} C a_{L}$ is essential for association with $\beta_{1}$-integrin. To determine whether the specific regions in the $\mathrm{COOH}$ terminus of $\alpha_{1 \mathrm{C}}$ are required for the association of $\alpha_{1 C}-\mathrm{Ca}_{\mathrm{L}}$ with $\alpha_{5} \beta_{1}$-integrin, three mutant $\alpha_{1 \mathrm{C}}-\mathrm{Ca}_{\mathrm{L}}$ constructs were overexpressed in HEK293-T cells (Fig. 1). If any of the specific regions is required for association between the two proteins, we predicted to observe less $\alpha_{1 \mathrm{C}}-\mathrm{Ca}_{\mathrm{L}}$ pulled down by anti- $\beta_{1}$-integrin $\mathrm{Ab}$ in cells expressing the mutant $\alpha_{1 \mathrm{C}}-\mathrm{Ca}_{\mathrm{L}}$. As shown in Fig. $4 A$, truncated $\alpha_{1 C^{-}} \mathrm{Ca}_{\mathrm{L}}$ exhibited a reduced level of association with $\beta_{1^{-}}$ integrin (lane 8) and a reduced level of association with c-Src (lane 7), compared with their respective levels of association in WT $\alpha_{1 \mathrm{C}}-\mathrm{Ca}_{\mathrm{L}}$ (lanes 1 and 2, respectively). Figure $4 B$ shows the same membrane after stripping and reprobing for $\beta_{1}$-integrin as a loading control. The expression of $\beta_{1}$-integrin, c-Src (Supplemental Fig. S3A), and the degrees of association between $\beta_{1}$-integrin and c-Src were not changed in cells expressing truncated $\alpha_{1 \mathrm{C}}-\mathrm{Ca}_{\mathrm{L}}$, compared with WT $\alpha_{1 C^{-}} \mathrm{Ca}_{\mathrm{L}}$ (quantified data not shown). When normalized to the total amount of WT $\alpha_{1 C^{-}} \mathrm{Ca}_{\mathrm{L}}$, the associations between truncated $\alpha_{1 C^{-}} \mathrm{Ca}_{\mathrm{L}}$ and $\beta_{1}$-integrin as well as between truncated $\alpha_{1 C^{-}} \mathrm{Ca}_{\mathrm{L}}$ and c-Src were reduced to $40 \pm$ $9 \%$ and $55 \pm 8 \%$ of $\mathrm{WT} \alpha_{1 \mathrm{C}}-\mathrm{Ca}_{\mathrm{L}}$, respectively (Fig. $4 C$ ).
Fig. 3. $\alpha_{1 \mathrm{C}}-\mathrm{Ca}_{\mathrm{L}}$ associates with $\beta_{1}$-integrin in arteriolar smooth muscle incubated with FN. A: representative blot showing co-IP protocol on protein lysed from arteriolar smooth muscle (pulled down with anti- $\alpha_{1 C}-\mathrm{Ca}_{\mathrm{L}}$ ). $\beta_{1}$-Integrin and $\alpha_{1 \mathrm{C}}-\mathrm{Ca}_{\mathrm{L}}$ coimmunoprecipitated when arterioles were incubated with FN for $1 \mathrm{~h}$ (lanes 1 and 2, respectively). Lanes 1 and 6 were immunoprecipitated with anti- $\alpha_{1 \mathrm{C}}-\mathrm{Ca}_{\mathrm{L}}$ from Chemicon, whereas lanes 2 and 5 were immunoprecipitated with anti- $\alpha_{1 C}-\mathrm{Ca}_{\mathrm{L}}$ from Abcam. Lanes 3 and 4 were lysates alone isolated from control arterioles or arterioles incubated with $\mathrm{FN}$, respectively. The absence of coimmunoprecipitated $\beta_{1}$-integrin by rabbit IgG (lane 7 ) indicates binding specificity. $B$ : representative blot showing co-IP protocol on protein lysed from arteriolar smooth muscle (pulled down with anti- $\alpha_{1 C^{-}}$ $\mathrm{Ca}_{\mathrm{L}}$ ). c-Src coimmunoprecipitated with $\alpha_{1 \mathrm{C}^{-}}$ $\mathrm{Ca}_{\mathrm{L}}$ whether or not arterioles were incubated with FN (lanes 1 and 2 vs. lanes 5 and 6 , respectively). IP was performed as described in A. Abluminal incubation of arterioles with exogenous FN did not change the degree of association between $\alpha_{1 C}-\mathrm{Ca}_{\mathrm{L}}$ and c-Src (lane 2, 90\% and lane 5, 86\% of arterioles alone, respectively). The absence of coimmunoprecipitated c-Src by rabbit IgG (lane 7) indicates binding specificity. $C$ : representative blot showing co-IP protocol on protein lysed from arteriolar smooth muscle (pulled down with anti- $\alpha_{1 \mathrm{C}}-\mathrm{Ca}_{\mathrm{L}}$ ). Phosphorylated c-Src was only observed in arterioles incubated with exogenous FN (lanes 1 and 2). IP was performed as described in $A$. The absence of phosphorylated c-Src by rabbit $\mathrm{IgG}$ (lane 7) indicates binding specificity.

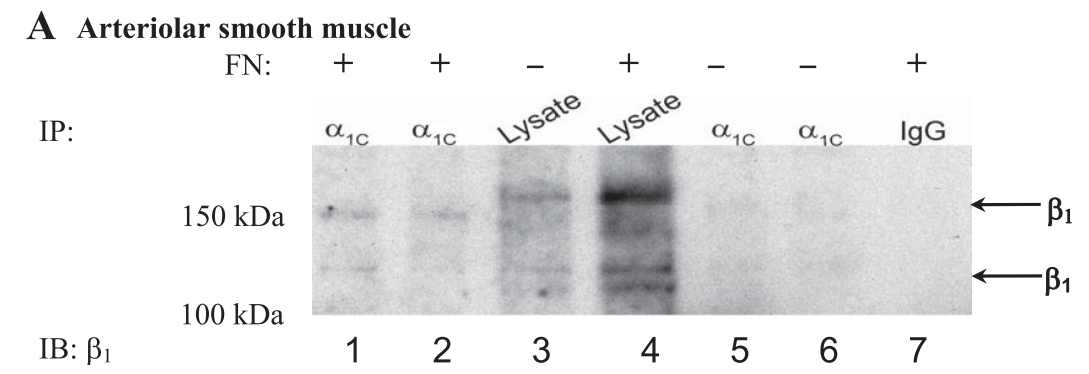

B Arteriolar smooth muscle
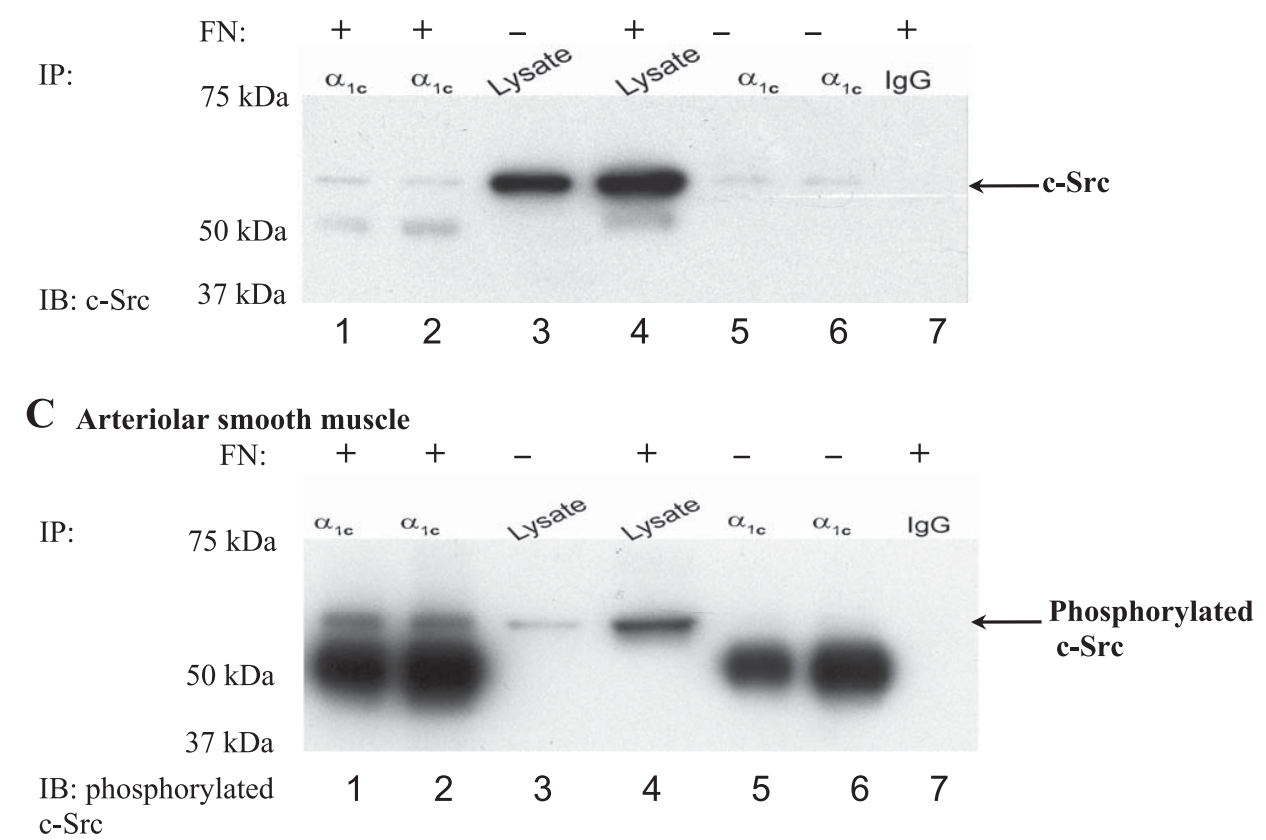


\section{A HEK293-T cells plated on fibronectin}

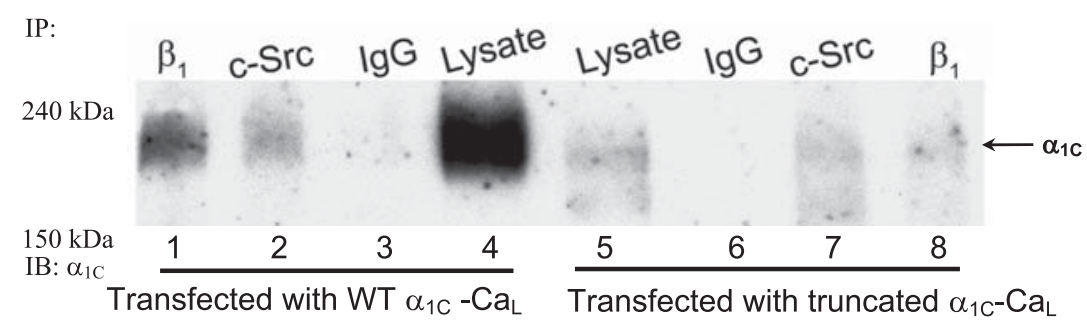

B

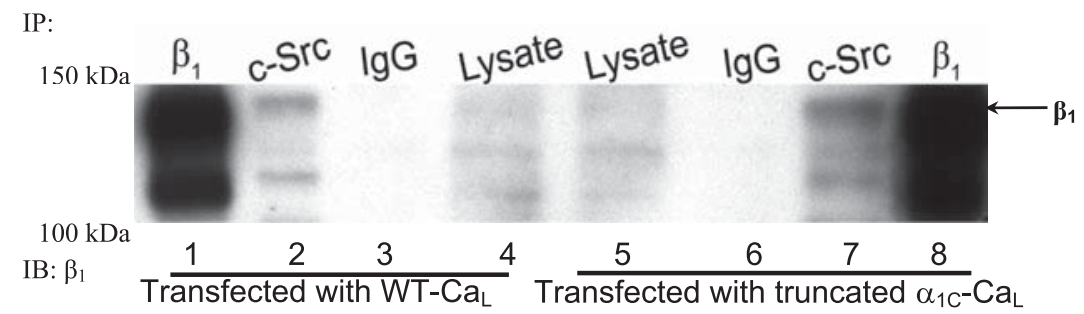

C

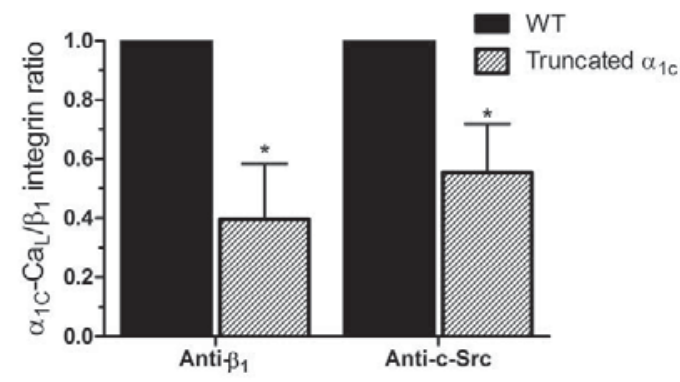

Fig. 4. Requirement of the $\alpha_{1 \mathrm{C}^{-}} \mathrm{Ca}_{\mathrm{L}} \mathrm{COOH}$ terminus for association of $\alpha_{1 \mathrm{C}}-\mathrm{Ca}_{\mathrm{L}}$ with c-Src or $\beta_{1}$-integrin. A: representative blot comparing WT- and truncated $\alpha_{1 C}-\mathrm{Ca}_{\mathrm{L}}$ immunoprecipitated with either anti-c-Src, anti- $\beta_{1}$-integrin $\mathrm{Ab}$, or mouse IgG, then probed for $\alpha_{1 \mathrm{C}}$. $\alpha_{1 \mathrm{C}}$ was only detected in lysates immunoprecipitated with anti-c-Src (lanes 2 and 7) or anti- $\beta_{1}$-integrin $\mathrm{Ab}$ (lanes 1 and 8 ) but not with mouse $\mathrm{IgG}$ (lanes 3 and 6 ). Relatively lower amounts of $\alpha_{1 C}-\mathrm{Ca}_{\mathrm{L}}$ were pulled down by anti-c-Src or anti- $\beta_{1}$-integrin $\mathrm{Ab}$ in truncated $\alpha_{1 \mathrm{C}}-\mathrm{Ca}_{\mathrm{L}}$ (lanes 7 and 8 , respectively), compared with WT. $B$ : the same blot in $A$ after stripping and reprobing for $\beta_{1}$-integrin as a control for IP and immunoblotting. $C$ : summary graph of the relative levels of immunoprecipitated $\alpha_{1 C}$ in cells expressing WT- or truncated $\alpha_{1 \mathrm{C}}-\mathrm{Ca}_{\mathrm{L}}$. Values were obtained as described in METHODS and are based on the average of at least three experiments. $* P<0.05$ vs. WT + anti- $\beta_{1}$-integrin Ab or WT + anti-c-Src Ab.
These results provide evidence for the requirement of the distal $\mathrm{COOH}$ terminus in the associations between $\alpha_{1 \mathrm{C}}-\mathrm{Ca}_{\mathrm{L}}$ and $\beta_{1}$-integrin and between $\alpha_{1 C^{-}}-a_{L}$ and $c-S r c$.

To confirm that the reduced associations between $\alpha_{1 \mathrm{C}}-\mathrm{Ca}$ and $\beta_{1}$-integrin and between $\alpha_{1 C^{-}}-\mathrm{Ca}_{\mathrm{L}}$ and $\mathrm{c}-\mathrm{Src}$ were not due to decreased expression of truncated $\alpha_{1 C}-\mathrm{Ca}_{\mathrm{L}}$ construct, we increased the amount of total protein for IP from cells expressing the truncated $\alpha_{1 C^{-}}-a_{L}$ construct to twofold that of WT $\alpha_{1 \mathrm{C}}-\mathrm{Ca}_{\mathrm{L}}$ and reexamined the association of truncated $\alpha_{1 \mathrm{C}}-\mathrm{Ca}_{\mathrm{L}}$ with $\beta_{1}$-integrin or with c-Src. As shown in Supplemental Fig. $\mathrm{S} 2, A$ and $C$, reduced degrees of association between $\alpha_{1 C^{-}} \mathrm{Ca}_{\mathrm{L}}$ and $\beta_{1}$-integrin (Fig. S2A, lane 3 ), $\alpha_{1 C^{-}} \mathrm{Ca}_{\mathrm{L}}$ and phosphorylated tyrosine (Tyr-Pi, Fig. S2A, lane 2), and $\alpha_{1 \mathrm{C}}-\mathrm{Ca}_{\mathrm{L}}$ and c-Src (Fig. S2A, lane 1) were still observed in cells expressing truncated $\alpha_{1 \mathrm{C}}-\mathrm{Ca}_{\mathrm{L}}$, when compared with the degrees of their respective associations in cells expressing WT $\alpha_{1 \mathrm{C}}-\mathrm{Ca}_{\mathrm{L}}(70 \pm$ $7 \%, 51 \pm 4 \%$, and $58 \pm 11 \%$; \% of WT, respectively). However, the expressions of $\beta_{1}$-integrin and $\mathrm{c}$-Src, the degrees of associations between $\beta_{1}$-integrin and $\mathrm{c}$-Src, or between $\beta_{1}$-integrin and proteins containing phosphorylated tyrosine were not changed in cells expressing truncated $\alpha_{1 \mathrm{C}}-\mathrm{Ca}_{\mathrm{L}}$, compared with WT $\alpha_{1 C}-\mathrm{Ca}_{\mathrm{L}}$ (Supplemental Figs. S2B and S3B; quantified data not shown). These results suggest a requirement for the distal $\mathrm{COOH}$ terminus in $\alpha_{1 \mathrm{C}}-\mathrm{Ca}_{\mathrm{L}}$ association with the $\beta_{1}$-integrin and c-Src.
The collaborative contribution of PKA and c-Src in the association of $\mathrm{Ca}_{L}$ with $\beta_{1}$-integrin. We previously showed that $\alpha_{5} \beta_{1}$-integrin engagement leads to potentiation of $\mathrm{Ca}_{\mathrm{L}}$ current via phosphorylation of $\alpha_{1 C^{-}} C_{a}$ serine $\left(S^{1901}\right)$ and tyrosine $\left(\mathrm{Y}^{2122}\right)$ by PKA and c-Src, respectively (14). Thus, a next logical step was to determine whether phosphorylation of $\alpha_{1 C}-\mathrm{Ca}_{\mathrm{L}}$ by PKA and $\mathrm{c}-\mathrm{Src}$ is required for $\mathrm{Ca}_{\mathrm{L}}$ association with $\beta_{1}$-integrin or c-Src. As shown in Fig. 5A, reduced associations between $\alpha_{1 \mathrm{C}}-\mathrm{Ca}_{\mathrm{L}}$ and $\beta_{1}$-integrin (lane 3 ), $\alpha_{1 \mathrm{C}}-\mathrm{Ca}_{\mathrm{L}}$ and Tyr-Pi (lane 2), and $\alpha_{1 \mathrm{C}^{-}}-\mathrm{Ca}_{\mathrm{L}}$ and c-Src (lane 1) were observed in cells expressing $\mathrm{S}^{1901} \mathrm{~A} / \mathrm{Y}^{2122} \mathrm{~F}-\mathrm{Ca}_{\mathrm{L}}$, compared with $\mathrm{WT} \alpha_{1 \mathrm{C}^{-}} \mathrm{Ca}_{\mathrm{L}}$ (Fig. $5 C, 47 \pm 8 \%, 48 \pm 12 \%$, and, $27 \pm 7 \%$; \% of WT, respectively). However, the expressions of $\beta_{1}$-integrin (Fig. $5 B$ ) and c-Src, the degrees of associations between $\beta_{1}$-integrin and c-Src, or between $\beta_{1}$-integrin and proteins containing phosphorylated tyrosine were unchanged in cells expressing $\mathrm{S}^{1901} \mathrm{~A} / \mathrm{Y}^{2122} \mathrm{~F}-\mathrm{Ca} \mathrm{L}_{\mathrm{L}}$, compared with WT $\alpha_{1 \mathrm{C}}-\mathrm{Ca}_{\mathrm{L}}$ (Supplemental Fig. S4A, quantified data not shown). These results suggest that phosphorylation of $\alpha_{1 C^{-}}-a_{L}$ by PKA and/or c-Src is required for the associations between $\alpha_{1 C^{-}} \mathrm{Ca}_{\mathrm{L}}$ and $\beta_{1}$-integrin and between $\alpha_{1 C^{-}} \mathrm{Ca}_{\mathrm{L}}$ and c-Src.

The proline-rich domains in the $\mathrm{COOH}$ terminus are required for the association of $\alpha_{1 C^{-}} C a_{L}$ with $\beta_{1}$-integrin. Prolinerich domains (PRDs) are binding motifs for Src homology 3 domain (SH3)-containing proteins, such as c-Src (34). Two 
A HEK293-T cells plated on fibronectin

Fig. 5. $\mathrm{S}^{1901}$ and $\mathrm{Y}^{2122}$ in $\alpha_{1 C}-\mathrm{Ca}_{\mathrm{L}}$ are required for $\alpha_{1 \mathrm{C}-\mathrm{Ca}}$ association with $\beta_{1}$-integrin or c-Src. A: representative blot comparing WT $\alpha_{1 \mathrm{C}}-\mathrm{Ca} a_{L}$ and $\mathrm{S}^{1901} \mathrm{~A} / \mathrm{Y}^{2122} \mathrm{~F} \alpha_{1 \mathrm{C}}-\mathrm{Ca}_{\mathrm{L}}$ immunoprecipitated with either anti-c-Src, anti-phosphorylated tyrosine (Tyr-Pi), or anti- $\beta_{1}$-integrin $\mathrm{Ab}$, and probed for $\alpha_{1 C}$. Relatively lower amounts of $\alpha_{1 C}-\mathrm{Ca}_{\mathrm{L}}$ appear to be pulled down by anti-c-Src, anti-Tyr-Pi, or anti- $\beta_{1}$-integrin $\mathrm{Ab}$ (lanes 1, 2, and 3, respectively) in $\mathrm{S}^{1901} \mathrm{~A} / \mathrm{Y}^{2122} \mathrm{~F}$ $\alpha_{1 \mathrm{C}}-\mathrm{Ca}_{\mathrm{L}}$-expressing cells, compared with WT- $\alpha_{1 \mathrm{C}}-\mathrm{Ca}_{\mathrm{L}}$. $B$ : the same blot in $A$ after stripping and reprobing for $\beta_{1}$-integrin. $C$ : summary graph showing the relative levels of immunoprecipitated $\alpha_{1 \mathrm{C}}$ in WT- or $\mathrm{S}^{1901} \mathrm{~A} / \mathrm{Y}^{2122} \mathrm{~F}-\mathrm{Ca}_{\mathrm{L}}$. Values were obtained as described in METHODS and are based on the average of at least three experiments. $* P<$ 0.05 vs. WT + anti- $\beta_{1}$-integrin $\mathrm{Ab}, \mathrm{WT}+$ anti-Tyr-Pi Ab, or WT + anti-c-Src Ab.

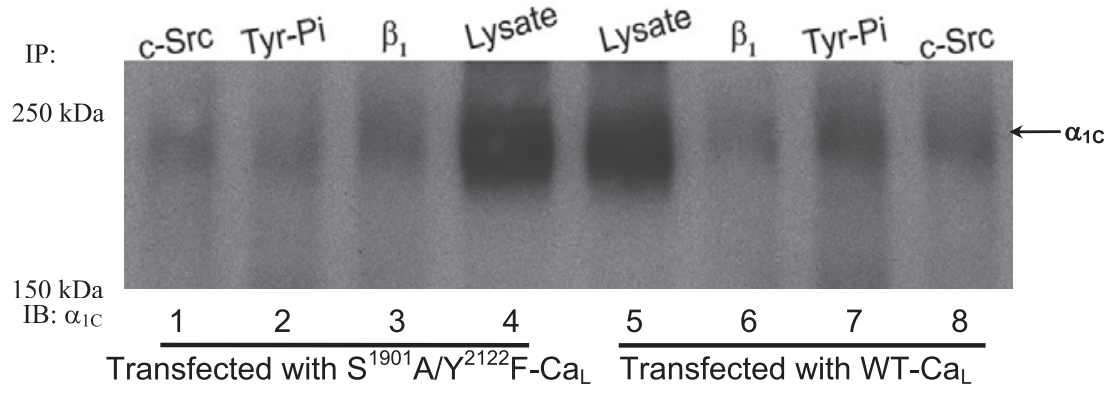

B HEK293-T cells plated on fibronectin

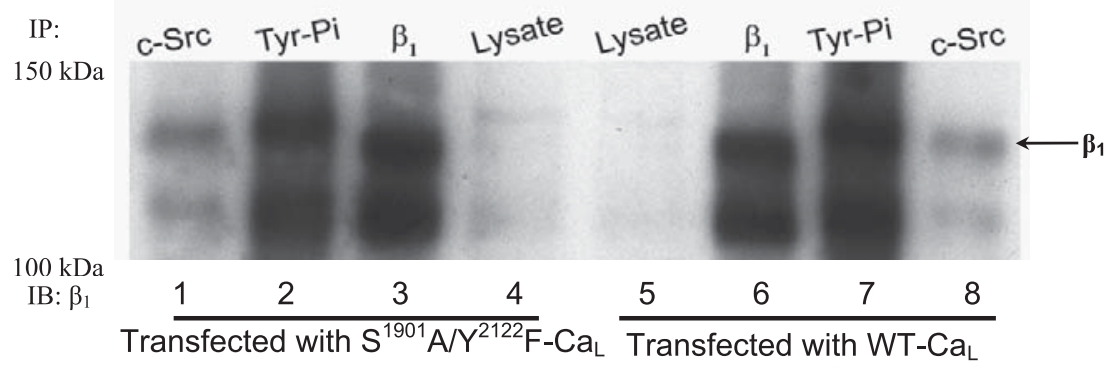

C

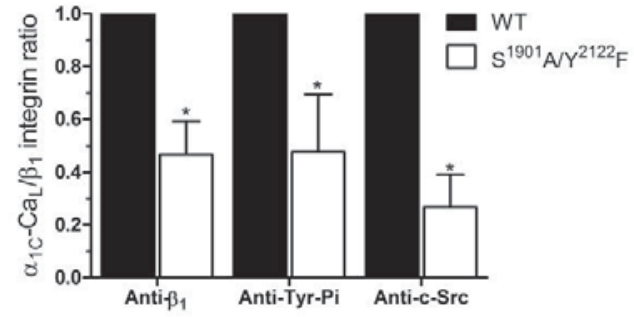

PRDs have been identified in the $\mathrm{COOH}$ terminus of $\alpha_{1 \mathrm{C}}-\mathrm{Ca}_{\mathrm{L}}$ and have been shown to mediate the association of $\mathrm{Ca}_{\mathrm{L}}$ with some proteins containing SH3 domains $(12,13)$. Thus, we investigated the roles of the $\mathrm{COOH}$-terminal PRDs in determining $\alpha_{1 C}-\mathrm{Ca}_{\mathrm{L}}$ association with $\beta_{1}$-integrin or $\mathrm{c}-\mathrm{Src}$ by expressing a $\Delta \mathrm{P} 1 / \Delta \mathrm{P} 2-\mathrm{Ca}_{\mathrm{L}}$ mutant with selective deletion of both PRDs in the $\mathrm{COOH}$ terminus of $\alpha_{1 \mathrm{C}}$. As shown in Fig. 6A, significantly less association between $\alpha_{1 \mathrm{C}}-\mathrm{Ca}_{\mathrm{L}}$ and $\beta_{1}$-integrin (lane 6) and between $\alpha_{1 \mathrm{C}}-\mathrm{Ca}_{\mathrm{L}}$ and c-Src (lane 8), was observed in cells expressing the $\Delta \mathrm{P} 1 / \Delta \mathrm{P} 2 \alpha_{1 C^{-}} \mathrm{Ca}_{\mathrm{L}}$ mutant, compared with WT $\alpha_{1 C^{-}} \mathrm{Ca}_{\mathrm{L}}$ (Fig. $6 C, 54 \pm 9 \%, 54 \pm 6 \%$; $\%$ of WT, respectively). However, the expression of $\beta_{1^{-}}$integrin (Fig. 6B), c-Src, and the degree of association between $\beta_{1}$-integrin and c-Src was unchanged in cells expressing $\Delta \mathrm{P} 1 / \Delta \mathrm{P} 2 \alpha_{1 \mathrm{C}^{-}} \mathrm{Ca}_{\mathrm{L}}$ (Supplemental Fig. S4B, quantified data not shown). These results suggest that the PRDs in the $\alpha_{1 \mathrm{C}}-\mathrm{Ca}_{\mathrm{L}} \mathrm{COOH}$ terminus are partially required for associations between $\alpha_{1 \mathrm{C}}-\mathrm{Ca}_{\mathrm{L}}$ and $\beta_{1}$-integrin and between $\alpha_{1 \mathrm{C}}-\mathrm{Ca}_{\mathrm{L}}$ and c-Src.

Functional modulation of $C a_{L}$ current by $\alpha_{5} \beta_{1}$-integrin is independent of the PRDs in the COOH terminus. Given the results shown in Figs. 5 and 6, we also investigated the roles of the two PRDs in the modulation of $\mathrm{Ca}_{\mathrm{L}}$ current following $\alpha_{5} \beta_{1}$-integrin engagement. As shown in Fig. $7 A$, the application of $\alpha_{5} \beta_{1}$-integrin antibody to the bath solution potentiated whole cell $\mathrm{Ca}_{\mathrm{L}}$ current in HEK293-T cells expressing WT-Ca $a_{L}$, consistent with our previous findings (14). To our surprise, no significant electrophysiological difference was observed between WT-Ca $a_{L}$ and $\Delta \mathrm{P} 1 / \Delta \mathrm{P} 2-\mathrm{Ca}_{\mathrm{L}}(82 \%$ of WT) in the degree of current potentiation by $\alpha_{5} \beta_{1}$-integrin engagement, suggesting that the $\mathrm{COOH}$-terminal PRDs are not required for potentiation of $\mathrm{Ca}_{\mathrm{L}}$ current by $\alpha_{5} \beta_{1}$-integrin engagement. When the degree of $\mathrm{Ca}_{\mathrm{L}}$ current potentiation following $\alpha_{5} \beta_{1}$-integrin ligation in the mutant constructs was normalized to that of WT, both the truncated $\alpha_{1 \mathrm{C}}-\mathrm{Ca}_{\mathrm{L}}$ and $\mathrm{S}^{1901} \mathrm{~A} / \mathrm{Y}^{2122} \mathrm{~F}-\mathrm{Ca}_{\mathrm{L}}$ mutants displayed significant impairment in the amount of current potentiation by integrin ligation (Fig. $7 B, 9 \%$ and $1 \%$ potentiation of $\mathrm{WT}-\mathrm{Ca}_{\mathrm{L}}$, respectively; see also Ref. 14). The above results confirm that $\mathrm{S}^{1901}$ and $\mathrm{Y}^{2122}$ residues in the $\mathrm{COOH}$ terminus of $\alpha_{1 \mathrm{C}}-\mathrm{Ca}_{\mathrm{L}}$ are required for $\mathrm{Ca}^{2+}$ current potentiation following $\alpha_{5} \beta_{1}$-integrin ligation. However, selective deletion of the two PRDs in the $\mathrm{COOH}$ terminus of $\alpha_{1 \mathrm{C}}-\mathrm{Ca}_{\mathrm{L}}$ does not impair the current potentiation by $\alpha_{5} \beta_{1}$-integrin engagement. 
A

HEK293-T cells plated on fibronectin

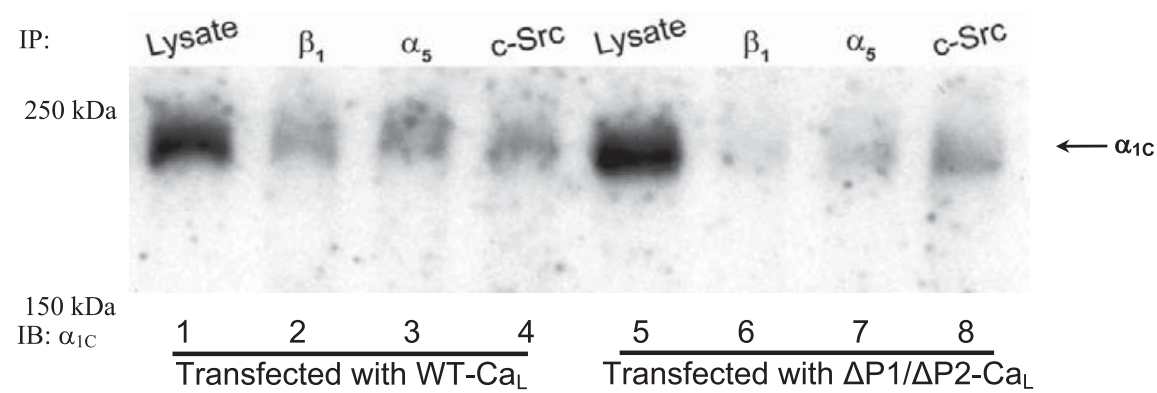

B HEK293-T cells plated on fibronectin

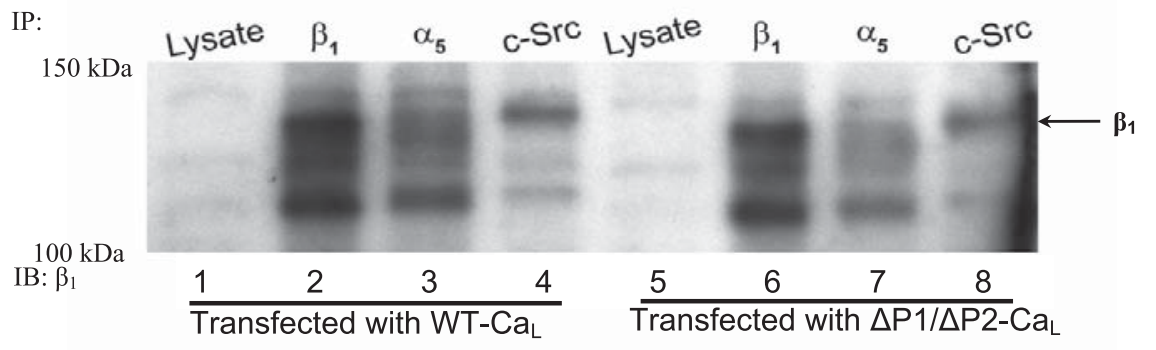

Fig. 6. Requirement of proline-rich domains (PRDs) in the $\alpha_{1 \mathrm{C}}-\mathrm{Ca}_{\mathrm{L}} \mathrm{COOH}$ terminus for $\alpha_{1 \mathrm{C}}-\mathrm{Ca}_{\mathrm{L}}$ association with $\beta_{1}$-integrin or c-Src. $A$ : representative blot comparing WT $\alpha_{1 C^{-}} \mathrm{Ca}_{\mathrm{L}}$ and $\Delta \mathrm{P} 1 / \Delta \mathrm{P} 2 \alpha_{1 \mathrm{C}^{-}} \mathrm{Ca}_{\mathrm{L}}$ immunoprecipitated with anti-c-Src, anti- $\alpha_{5}$-integrin, or anti$\beta_{1}$-integrin $\mathrm{Ab}$ and probed for $\alpha_{1 \mathrm{C}}$. Relatively lower amounts of $\alpha_{1 C}-\mathrm{Ca}_{\mathrm{L}}$ appear to be pulled down by anti-c-Src or anti- $\beta_{1}$-integrin $\mathrm{Ab}$ (lanes 8 and 6 , respectively) in cells expressing $\Delta \mathrm{P} 1 / \Delta \mathrm{P} 2 \alpha_{1 \mathrm{C}}-\mathrm{Ca}_{\mathrm{L}}$, compared with WT $\alpha_{1 \mathrm{C}}-\mathrm{Ca}$. $B$ : the same blot in $A$ after stripping and reprobing for $\beta_{1}$-integrin. $C$ : summary graph showing the relative levels of immunoprecipitated $\alpha_{1 C}$ in WT- or $\Delta \mathrm{P} 1 / \Delta \mathrm{P} 2-\mathrm{Ca}_{\mathrm{L}}$. Values were obtained as described in METHODS and are based on the average of at least three experiments. $* P<0.05$ vs. WT + anti-c-Src $\mathrm{Ab}$ or $\mathrm{WT}+$ anti- $\beta_{1}$-integrin $\mathrm{Ab}$.

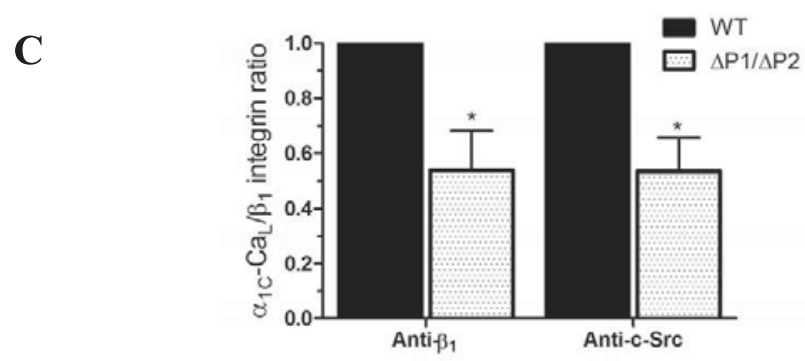

Immunofluorescence imaging analysis demonstrates association of $\mathrm{Ca}_{L}$ with $\beta_{1}$-integrin on the plasma membrane. The $\mathrm{COOH}$ terminus of $\alpha_{1 \mathrm{C}}-\mathrm{Ca}_{\mathrm{L}}$ has been shown to mediate membrane targeting of the channel (11), so we further investigated the effect of the abovementioned regions in the $\mathrm{COOH}$ terminus on membrane targeting of $\alpha_{1 C^{-}}-\mathrm{Ca}_{\mathrm{L}}$ and its association with $\beta_{1}$-integrin. Immunofluorescence confocal microscopy (IF) was performed to determine the expression, distribution, and relative localization of $\alpha_{1 C^{-}} \mathrm{Ca}_{L}$ and $\beta_{1}$-integrin on the plasma membrane. Images of cells without staining or cells stained with either anti-mouse $\mathrm{IgG}$, anti-rabbit $\mathrm{IgG}$, or the combination of both, exhibited only faint, diffuse, and nonspecific staining (Supplemental Fig. S5). As shown in Fig. 8, neither the membrane expression of $\alpha_{1 C^{-}} \mathrm{Ca}_{\mathrm{L}}$ nor $\beta_{1}$-integrin was detectably altered in $\mathrm{S}^{1901} \mathrm{~A} / \mathrm{Y}^{2122} \mathrm{~F}-\mathrm{Ca}_{\mathrm{L}}$, truncated $\alpha_{1 \mathrm{C}}-\mathrm{Ca}_{\mathrm{L}}$, or $\Delta \mathrm{P} 1 /$ $\Delta \mathrm{P} 2-\mathrm{Ca}_{\mathrm{L}}$, compared with WT-Ca .

When we examined the association between WT $\alpha_{1 \mathrm{C}}-\mathrm{Ca}_{\mathrm{L}}$ and endogenous $\beta_{1}$-integrin on the plasma membrane, a moderate degree of colocalization was observed. To quantify the degree of colocalization between $\alpha_{1 C^{-}}-\mathrm{Ca}_{\mathrm{L}}$ and $\beta_{1}$-integrin, we used the overlap of paxillin and vinculin staining as a normalization standard for the following analyses, since these two proteins highly associate at the focal adhesion site (ICA value 0.25) (37). The relatively high degree of colocalization between paxillin and vinculin was set as $100 \%$ for subsequent analysis of colocalization between $\alpha_{1 C}-\mathrm{Ca}_{\mathrm{L}}$ and $\beta_{1}$-integrin. We used Pearson's coefficient $(R)$, Mander's coefficient $\left(R_{\mathrm{r}}\right)$, and ICA to determine the degree of $\alpha_{1 C}-\mathrm{Ca}_{\mathrm{L}}-\beta_{1}$-integrin colocalization, as listed in Table 1 . The degrees of $\alpha_{1 C}-\mathrm{Ca}_{\mathrm{L}}$ colocalization with $\beta_{1}$-integrin in $\mathrm{WT}-\mathrm{Ca}_{\mathrm{L}}$, truncated $\alpha_{1 \mathrm{C}}-\mathrm{Ca}_{\mathrm{L}}$,

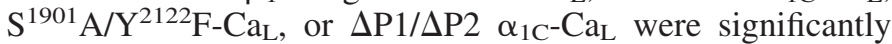
less than the degree of colocalization between paxillin and vinculin (60-88\% of paxillin-vinculin colocalization).

Using ICA analysis (Fig. 9), modest, but not significant, decreases in the degrees of $\alpha_{1 C}-C_{L}$ association with $\beta_{1}$ integrin were observed in the truncated $\alpha_{1 \mathrm{C}}-\mathrm{Ca}_{\mathrm{L}}, \mathrm{S}^{1901} \mathrm{~A} /$ $\mathrm{Y}^{2122} \mathrm{~F} \alpha_{1 C^{-}} \mathrm{Ca}_{\mathrm{L}}$, and $\Delta \mathrm{P} 1 / \Delta \mathrm{P} 2 \alpha_{1 \mathrm{C}^{-}} \mathrm{Ca}_{\mathrm{L}}$ mutants, compared with WT-Ca $-a_{L}(99 \pm 5.9 \%, 99 \pm 6.2 \%$, and $88 \pm 5.1 \%$ of WT $\alpha_{1 \mathrm{C}}-\mathrm{Ca}_{\mathrm{L}}$, respectively). Deconvolution analysis was also used to eliminate the signals collected from out-of-focus emission. However, no substantial differences were noted in the same comparisons when deconvolution analysis was applied (data not shown). Collectively, confocal image analysis demonstrated that the association between $\alpha_{1 C^{-}}-\mathrm{Ca}_{\mathrm{L}}$ and $\beta_{1}$-integrin on the cell membrane was moderate in cells expressing WT $\alpha_{1 \mathrm{C}}-\mathrm{Ca}_{\mathrm{L}}$. No significant differences were observed in the degree of $\alpha_{1 C^{-}}-a_{L}$ colocalization with $\beta_{1}$-integrin between the three mutant $\alpha_{1 C^{-}}-\mathrm{Ca}_{\mathrm{L}}$ constructs, compared with WT $\alpha_{1 C^{-}} \mathrm{Ca}_{\mathrm{L}}$. Taken together, the IF results suggest that $\alpha_{1 C^{-}} \mathrm{Ca}_{\mathrm{L}}$ and $\beta_{1^{-}}$ integrin colocalize to a moderate degree on the plasma mem- 
$\mathbf{A}$

Fig. 7. Electrophysiological protocols to determine the effects of $\mathrm{COOH}$ terminus-specific regions on modulation of $\mathrm{Ca}_{\mathrm{L}}$ current by $\alpha_{5} \beta_{1}$-integrin. $A$ : representative recordings of whole cell $\mathrm{Ca}_{\mathrm{L}}$ current from HEK293-T cells expressing WT-Ca $\mathrm{L}_{\mathrm{L}}$ (left) or $\Delta \mathrm{P} 1 / \Delta \mathrm{P} 2-\mathrm{Ca}_{\mathrm{L}}$ $(r i g h t)$. Top traces in both panels show the amount of basal current in cells expressing WT- or $\Delta \mathrm{P} 1 / \Delta \mathrm{P} 2-\mathrm{Ca}_{\mathrm{L}}$, and bottom traces show the current potentiation by $\alpha_{5} \beta_{1}$-integrin Ab $(10 \mu \mathrm{g} / \mathrm{ml})$. No substantial difference in the relative amount of $\mathrm{Ca}_{\mathrm{L}}$ current potentiation was observed in cells expressing $\Delta \mathrm{P} 1 /$ $\Delta \mathrm{P} 2-\mathrm{Ca}_{\mathrm{L}}$, compared with WT-CaL. $B$ : summary graph showing peak current potentiation by $\alpha_{5} \beta_{1}$-integrin in WT-Ca $a_{L}$, truncated $\alpha_{1 C^{-}}$ $\mathrm{Ca}_{\mathrm{L}}$, or $\Delta \mathrm{P} 1 / \Delta \mathrm{P} 2-\mathrm{Ca}_{\mathrm{L}}$. CaL current potentiated by $\alpha_{5} \beta_{1}$-integrin $\mathrm{Ab}$ was significantly attenuated in truncated $\alpha_{1 \mathrm{C}-} \mathrm{Ca}_{\mathrm{L}}$ or in $\mathrm{S}^{1901} \mathrm{~A} /$ $\mathrm{Y}^{2122} \mathrm{~F}-\mathrm{Ca}_{\mathrm{L}}$, but not in $\Delta \mathrm{P} 1 / \Delta \mathrm{P} 2-\mathrm{Ca}_{\mathrm{L}}$. Number of cells recorded is as follows: WT-Ca $a_{L}$, $n=18 ; n=8$ in cells expressing $\Delta \mathrm{P} 1 / \Delta \mathrm{P} 2$ $\mathrm{Ca}_{\mathrm{L}}, \mathrm{S}^{1901} \mathrm{~A} / \mathrm{Y}^{2122} \mathrm{~F}-\mathrm{Ca} \mathrm{L}_{\mathrm{L}}$, or truncated $\alpha_{1 \mathrm{C}^{-}}$ Ca $a_{L} * P<0.05$ vs. WT-CaL.

B
WT
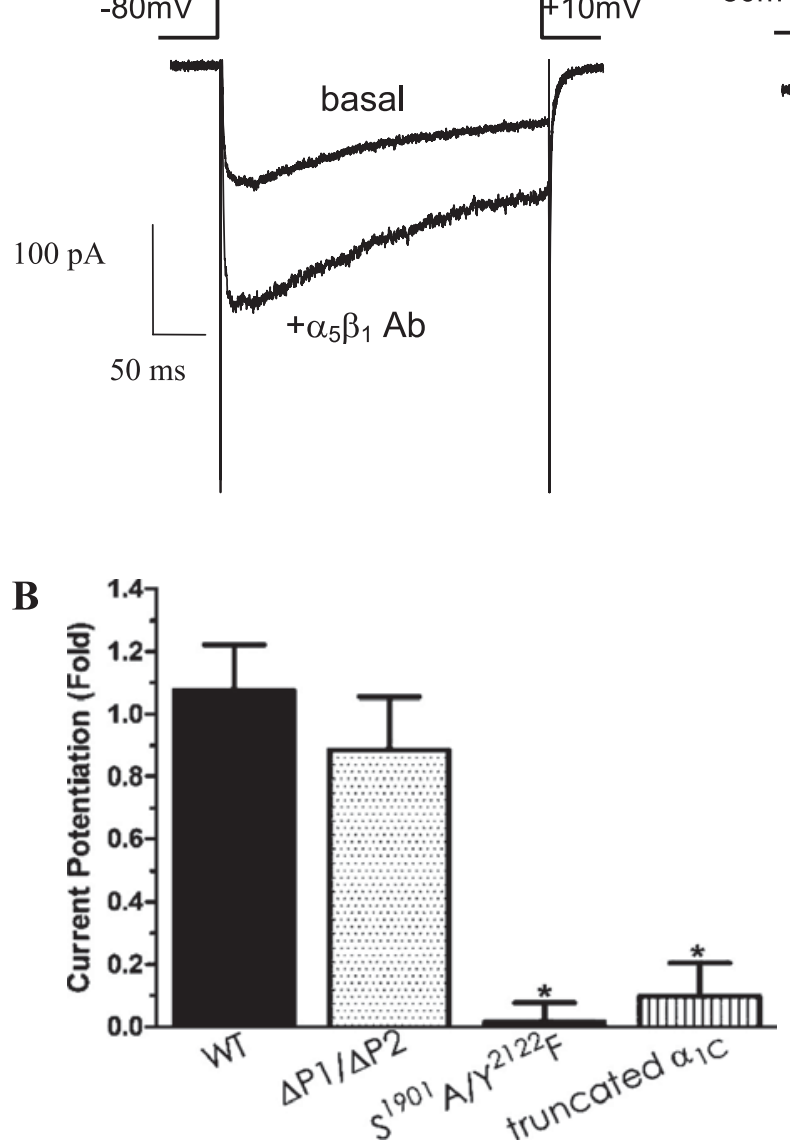

$\Delta \mathrm{P} 1 / \Delta \mathrm{P} 2$

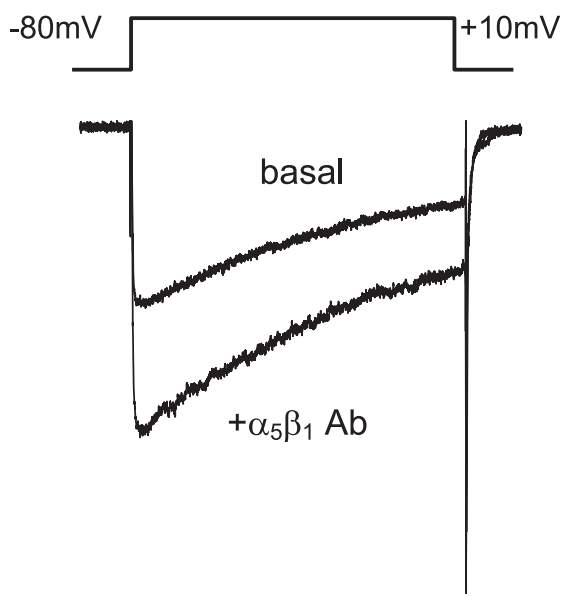

brane and that the modifications we made in the $\mathrm{COOH}$ terminus of $\alpha_{1 \mathrm{C}}-\mathrm{Ca}_{\mathrm{L}}$ did not significantly alter the membrane targeting of $\alpha_{1 \mathrm{C}}-\mathrm{Ca}_{\mathrm{L}}$ or $\beta_{1}$-integrin on the plasma membrane. Thus, the reduced associations between the mutant forms of $\alpha_{1 \mathrm{C}}-\mathrm{Ca}_{\mathrm{L}}$ and $\beta_{1}$-integrin observed in IP protocol are not due to deficient membrane targeting.

\section{DISCUSSION}

We present evidence that the pore-forming $\alpha_{1 \mathrm{C}}$-subunit of the L-type calcium channel $\left(\alpha_{1 C^{-}}-\mathrm{Ca}_{\mathrm{L}}\right)$ associates with $\beta_{1^{-}}$ integrin and c-Src in arteriolar SM as well as when the channel is heterologously expressed in HEK293-T cells. These associations depend on interactions of the cells with the ECM protein $\mathrm{FN}$, which is known from previous studies to potentiate $\mathrm{Ca}_{\mathrm{L}}$ current following $\alpha_{5} \beta_{1}$-integrin engagement (40). Furthermore, our results show that the associations between $\alpha_{1 C^{-}} \mathrm{Ca}_{\mathrm{L}}$ and $\alpha_{5} \beta_{1}$-integrin and between $\alpha_{1 C^{-}} \mathrm{Ca}_{\mathrm{L}}$ and $\mathrm{c}$-Src require specific regions in the $\mathrm{COOH}$ terminus of $\alpha_{1 \mathrm{C}}-\mathrm{Ca}_{\mathrm{L}}$. Two specific domains that are critical for these interactions are the PKA and c-Src phosphorylation sites that we previously identified as essential for modulation of $\mathrm{Ca}_{\mathrm{L}}$ function following $\alpha_{5} \beta_{1}$-integrin engagement (14). In addition, we found that $\mathrm{Ca}_{\mathrm{L}}$ preferentially associates with the phosphorylated, active, form of c-Src in arteriolar SM and that this association depends on FN. The latter result provides evidence for a unique local functional regulation of $\mathrm{Ca}_{\mathrm{L}}$ by $\alpha_{5} \beta_{1}$-integrin through phosphorylation of c-Src. Collectively, our data support the concept of a macromolecular complex composed of multiple focal adhesion molecules including PKA, c-Src, and some fraction of the $\mathrm{Ca}_{\mathrm{L}}$ population, which is assembled upon integrin ligation and required for potentiation of $\mathrm{Ca}_{\mathrm{L}}$ current following $\alpha_{5} \beta_{1}$-integrin engagement.

In this study, three different approaches, IP, IF, and patchclamp recording of $\mathrm{Ca}_{\mathrm{L}}$ current, were used to assess structural and functional interactions between $\alpha_{1 C}-\mathrm{Ca}_{\mathrm{L}}$ and $\alpha_{5} \beta_{1}$-integrin. In some respects, the data obtained using these methods support each other, while in other respects the data conflict. How can we reconcile the conflicting results? What do the collective data tell us about the direct or indirect association of the channel with $\alpha_{5} \beta_{1}$-integrin? What signaling components are required to mediate $\alpha_{1 C^{-}}-\mathrm{Ca}_{\mathrm{L}}$ association with $\alpha_{5} \beta_{1}$-integrin upon adhesion to $\mathrm{FN}$ ? How does the spatial interaction between $\alpha_{1 C^{-}}-a_{L}$ and $\alpha_{5} \beta_{1}$-integrin contribute to the functional regulation of $\mathrm{Ca}_{\mathrm{L}}$ ? What is the physiological significance of $\alpha_{1 \mathrm{C}}-\mathrm{Ca}_{\mathrm{L}}$ association with $\alpha_{5} \beta_{1}$-integrin? These issues will be addressed in the following sections.

Direct or indirect association of $C a_{L}$ with $\alpha_{5} \beta_{1}$-integrin. After demonstrating an association between $\alpha_{1 C^{-}}-a_{L}$ and $\alpha_{5} \beta_{1}$-integrin, using IP and IB methods, we sought to determine the nature of the interaction and the regions in $\alpha_{1 C^{-}}-\mathrm{Ca}_{\mathrm{L}}$ that were required. Because the crystal structure of $\alpha_{1 C^{-}} \mathrm{Ca}_{\mathrm{L}}$ has not been resolved, interactions between these proteins are difficult to predict. If $\alpha_{1 C^{-}} \mathrm{Ca}_{\mathrm{L}}$ directly interacts with $\alpha_{5} \beta_{1^{-}}$ integrin, a potential binding region would be the canonical 

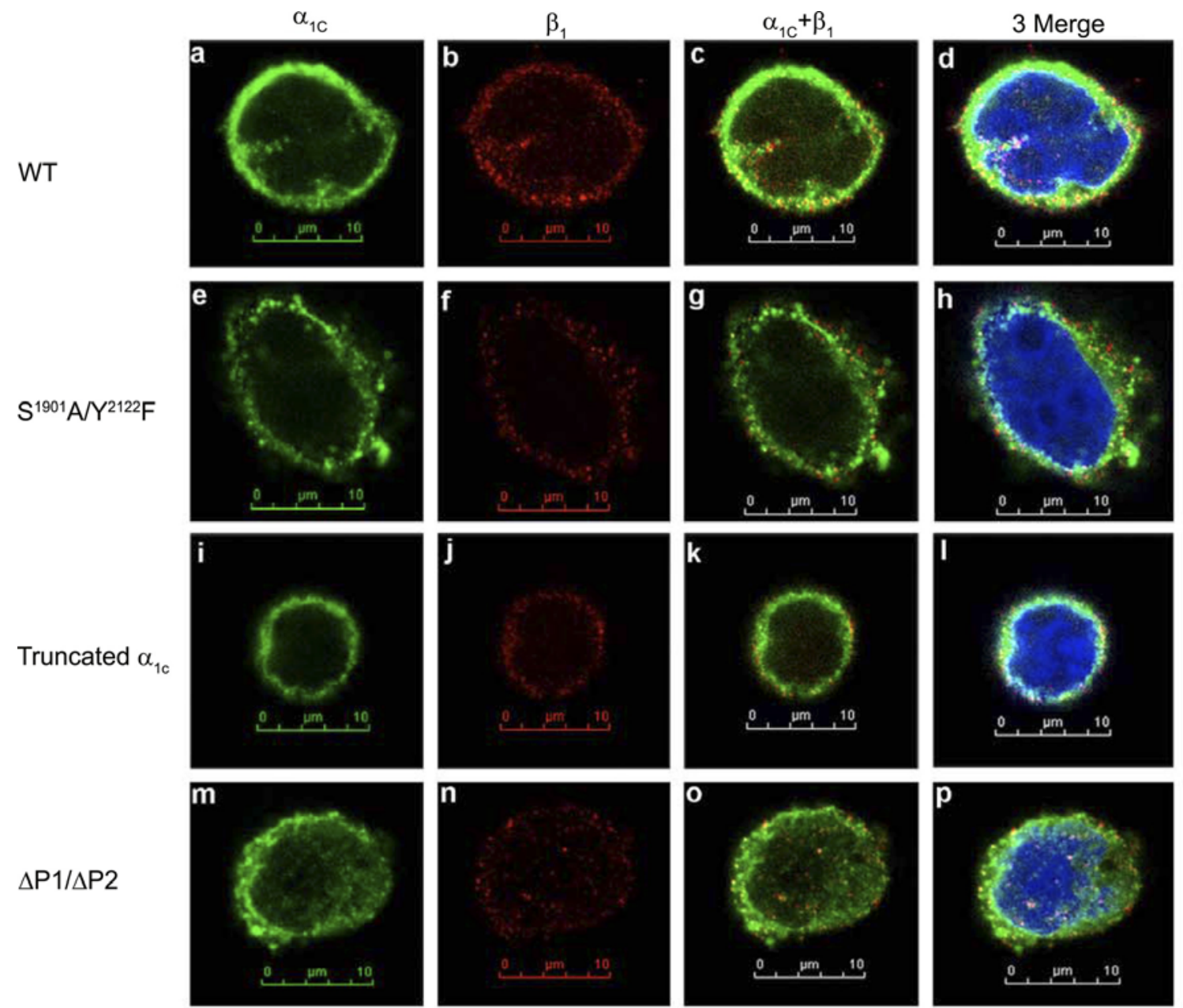

Paxillin(P)

Vinculin (V)

$\mathrm{P}+\mathrm{V}$
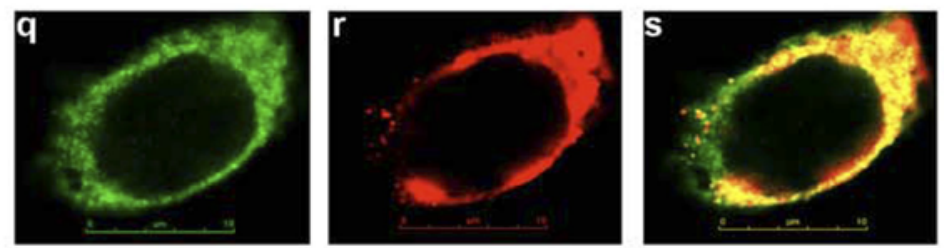

3 Merge

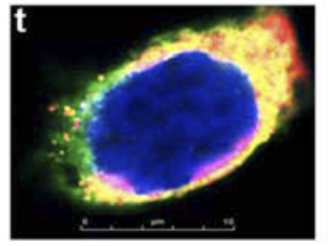

Fig. 8. Confocal immunofluorescence image analysis to determine the distribution and association of $\alpha_{1 C}-C a_{L}$ and $\beta_{1}$-integrin on the plasma membrane. Representative confocal immunofluorescence images from the cells expressing WT-, truncated $\alpha_{1 C^{-}}, \mathrm{S}^{1901} \mathrm{~A} / \mathrm{Y}^{2122} \mathrm{~F}-$, or $\Delta \mathrm{P} 1 / \Delta \mathrm{P} 2-\mathrm{Ca}$. $\alpha_{1 \mathrm{C}}$ and endogenous $\beta_{1}$-integrin expression on the plasma membrane appear as green and red punctate staining in $a, e, i$, and $m$ and in $b, f, j$, and $n$, respectively. The colocalization of $\alpha_{1 C}-C_{L}$ with $\beta_{1}$-integrin on the membrane appears as yellow to orange punctate staining $\left(c, g, k\right.$, and $o$ ). A noticeably higher degree of $\alpha_{1 C}-C a_{L}$ colocalization with $\beta_{1}$-integrin was seen in cells expressing WT- $\alpha_{1 C}-\mathrm{Ca}_{\mathrm{L}}$, compared with mutant $\alpha_{1 C}-\mathrm{Ca}_{\mathrm{L}}$ construct-expressing cells. Merged images of the previous three panels with nuclei counterstaining appear in blue $(d, h, l$, and $p)$. Endogenous paxillin and vinculin staining in HEK293-T cells appears as green and red in $q$ and $r$, respectively. The degree of colocalization between paxillin and vinculin (yellow to orange staining; $s$ ) appears to be much higher than that between $\alpha_{1 C}-C_{\mathrm{L}}$ and $\beta_{1}$-integrin in the WT- or mutant $\alpha_{1 C^{-}} \mathrm{Ca}_{\mathrm{L}}$-expressing cells. Merged image with nuclear counterstaining in blue appears in $t$. Magnification, $\times 63$ oil; scale bar, $10 \mu \mathrm{m}$.

Arg-Gly-Asp (RGD)-integrin-binding motif. In fact, a previous study by McPhee et al. (31) identified the functional significance of an RGD sequence located in the extracellular loop, between the first membrane-spanning region and the pore, of the $\mathrm{G}$ protein-activated inward rectifier $\mathrm{K}^{+}$channel (GIRK). This RGD sequence mediates the direct interaction between GIRK and the $\beta_{1}$-integrin. The functional significance of the interaction appears to involve targeting of GIRK to the plasma membrane and/or regulation of its stability rather than acute regulation of channel function (31). However, in Cav1.2, the only conserved RGD sequence (aa 448-450) is found in a conserved transmembrane region of all three $\mathrm{Ca}_{\mathrm{L}}$ isoforms, so that direct binding of $\alpha_{1 C}-C_{L}$ to RGD-binding integrins is unlikely due to potential steric hindrance. Thus, an indirect association between $\alpha_{1 C^{-}} \mathrm{Ca}_{\mathrm{L}}$ and $\alpha_{5} \beta_{1}$-integrin through cytoplasmic or cytoskeletal proteins seems more probable.

To determine regions in $\alpha_{1 \mathrm{C}}-\mathrm{Ca}_{\mathrm{L}}$ that provide binding motifs for other focal adhesion proteins that are known to associate with $\alpha_{5} \beta_{1}$-integrin, we used a site-directed mutagenesis strategy. On the basis of differences in the amount of coimmuno- 
Table 1. Semiquantitative analysis of $C a_{L}$ association with $\beta_{1}$-integrin

\begin{tabular}{lcccc}
\hline \hline & $R_{\mathrm{r}}, \%$ of Pax + Vin & $R, \%$ of Pax + Vin & ICA, \% & ICA, \% of Pax + Vin \\
\hline Paxillin-vinculin & 100 & 100 & $0.251 \pm 0.021$ & $0.22 \pm 0.009$ \\
WT & $60.6 \pm 2.7$ & $88.5 \pm 1.5$ & $0.211 \pm 0.01$ & $85.1 \pm 4.2$ \\
Truncated- $\alpha_{1 C}$ & $59.2 \pm 4.8$ & $87.9 \pm 2.6$ & $0.21 \pm 0.011$ & $84.1 \pm 5.0$ \\
$\mathrm{~S}^{1901} \mathrm{~A} / \mathrm{Y}^{2122} \mathrm{~F}$ & $56.5 \pm 4.5$ & $84.5 \pm 2.5$ & $0.185 \pm 0.013$ & $84.8 \pm 5.3$ \\
$\Delta \mathrm{P} 1 / \mathrm{P} 2$ & $55.4 \pm 5.1$ & $84.1 \pm 1.7$ & $75.2 \pm 7.4$ \\
\hline
\end{tabular}

Values are means \pm SE, taken from at least eight cells in either wild-type (WT) or mutant L-type voltage-gated Cav1.2 calcium channel $\left(\mathrm{Ca}_{\mathrm{L}}\right)$ per experiment. The degree of $\mathrm{Ca}_{\mathrm{L}}$ association with $\beta_{1}$-integrin was normalized using the association of paxillin (Pax) and vinculin (Vin) as a reference and set as $100 \%$ for Pearson's, Mander's, or intensity correlation analysis (ICA). The value of $\mathrm{Ca}_{\mathrm{L}}$ association with $\beta_{1}$-integrin in WT, truncated $\alpha_{1 C^{-}}, \mathrm{S}^{1901} \mathrm{~A} / \mathrm{Y}^{2122} \mathrm{~F}$, or $\Delta \mathrm{P} 1 / \Delta \mathrm{P} 2-\mathrm{Ca}_{\mathrm{L}}$ is presented as the percentage $\pm \mathrm{SE}$ of paxillin-vinculin association. $R_{\mathrm{r}}$, Pearson's coefficient; $R$, Mander's coefficient. Statistical analysis was performed on the basis of the average from at least four individual experiments.

precipitated $\alpha_{1 C}-\mathrm{Ca}_{\mathrm{L}}$ with $\beta_{1}$-integrin in WT versus mutated $\alpha_{1 C^{-}}-a_{L}$, we identified several regions in the $\alpha_{1 C^{-}} \mathrm{Ca}_{L} \mathrm{COOH}$ terminus that are involved in the interaction of $\alpha_{1 C^{-}} \mathrm{Ca}_{\mathrm{L}}$ with $\alpha_{5} \beta_{1}$-integrin: two phosphorylation sites for PKA and c-Src, along with the PRDs. These findings therefore implicate PKA, c-Src, and potentially other SH3 domain-containing proteins in mediating the interaction of $\alpha_{1 C}{ }^{-C} a_{L}$ with $\alpha_{5} \beta_{1}$-integrin.

The roles of PKA in the functional regulation of $C a_{L}$ and its association with $\alpha_{5} \beta_{1}$-integrin. PKA is known to regulate all three $\mathrm{Ca}_{\mathrm{L}}$ isoforms. In neurons, PKA colocalizes with adenylate cyclase, $\beta_{2}$-adrenergic receptor $\left(\beta_{2}\right.$-AR), A-kinase anchoring protein (AKAP), and protein phosphatase (PP2A) in a macromolecular signaling complex; PKA mediates the increase in neuronal $\mathrm{Ca}_{\mathrm{L}}$ current following stimulation of $\beta_{2}-\mathrm{AR}$ (6). Our results suggest that PKA is also a component of another macromolecular complex containing various focal adhesion proteins recruited following ligation of $\alpha_{5} \beta_{1}$-integrin and that signaling between proteins in this complex also can exert a significant degree of control over $\mathrm{Ca}_{\mathrm{L}}$ function. Evidence to support this conclusion derives from two aspects of our results. First, reduced association between $\alpha_{1 C^{-}}-\mathrm{Ca}_{L}$ and $\beta_{1}$-integrin was observed in an $\alpha_{1 C}-C_{2}$ mutant with altered PKA and c-Src phosphorylation sites. Second, our previous

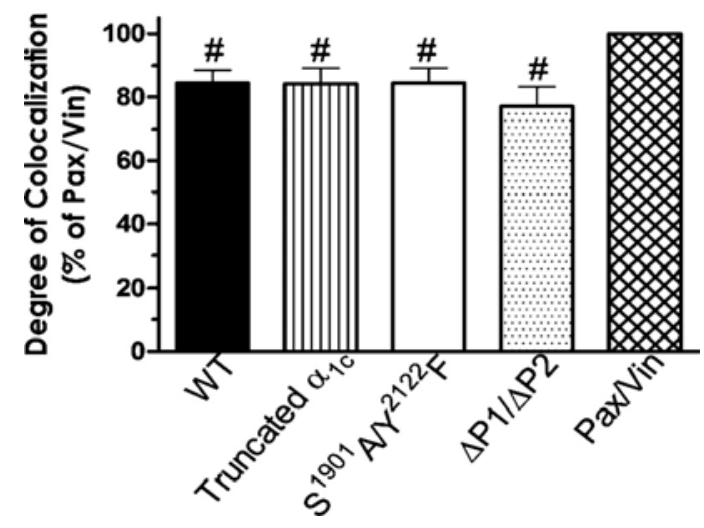

Fig. 9. Bar graph showing the quantified degree of $\alpha_{1 \mathrm{C}}-\mathrm{Ca}_{\mathrm{L}}$ association with $\beta_{1}$-integrin normalized to the degree of paxillin (Pax)-vinculin (Vin) association using intensity correlation analysis (ICA). The association of paxillin with vinculin was set as $100 \%$. The ICA value of $\alpha_{1 C}-\mathrm{Ca}_{\mathrm{L}}-\beta_{1}$-integrin association in WT $\alpha_{1 C^{-}}-a_{L}$, truncated $\alpha_{1 C}-C_{L}, S^{1901} \mathrm{~A} / \mathrm{Y}^{2122} \mathrm{~F}^{2} \alpha_{1 \mathrm{C}}-\mathrm{Ca}$, or $\Delta \mathrm{P} 1 / \Delta \mathrm{P} 2$ $\alpha_{1 C}-\mathrm{Ca}_{\mathrm{L}}$ is presented as the percentage of paxillin-vinculin association. Values were taken from at least 8 cells in either WT- or mutant $\mathrm{Ca}_{\mathrm{L}}$ per experiment, and the values in the graph were calculated on the basis of the average of at least four experiments. Statistical analysis was performed on the basis of the average from at least four individual experiments. $\# P<0.01 \mathrm{vs}$. the degree of colocalization between paxillin and vinculin. electrophysiological studies demonstrated a substantial reduction in the amount of $\mathrm{Ca}_{\mathrm{L}}$ current that was potentiated following ligation of $\alpha_{5} \beta_{1}$-integrin when $\alpha_{1 C}-\mathrm{Ca}_{\mathrm{L}}$ mutants with altered PKA and/or c-Src phosphorylation were used (14). When $S^{1901}$ in $\alpha_{1 C}$ is mutated, it not only leads to reduction in the association between $\alpha_{1 C^{-}} \mathrm{Ca}_{\mathrm{L}}$ and $\beta_{1}$-integrin, but also to reduction in the phosphorylation of $\mathrm{Ca}_{\mathrm{L}}$ by PKA (14). Findings from other laboratories also support the notion that $S^{1901}$ in the $\mathrm{COOH}$ terminus of $\alpha_{1 C^{-}}-\mathrm{Ca}_{\mathrm{L}}$ is a focal assembly point for PKA, AKAP, PP2A, and WAVE/WASP, which collectively modulate $\mathrm{Ca}_{\mathrm{L}}$ function (5). In support of this idea, the macromolecular complex composed of PKA, AKAP, PP2A, and WAVE/ WASP has been shown to provide a spatial link to the integrincytoskeleton network in modulation of other cellular functions (15) and engagement of $\beta_{1}$-integrin is known to facilitate PKA targeting to specific cellular locations $(26,32)$. On the basis of all the above, faulty trafficking/targeting of PKA in the cytoplasm could contribute to reduced interaction of PKA with other focal adhesion components in the macromolecular complex, thereby disrupting the spatial link to the integrin-cytoskeleton network and reducing the extent to which $\mathrm{Ca}_{\mathrm{L}}$ function is influenced by $\alpha_{5} \beta_{1}$-integrin signaling.

The roles of PRDs and c-Src in functional regulation of $C a_{L}$ and its association with $\alpha_{5} \beta_{1}$-integrin. c-Src is another kinase that is implicated in the signaling pathway between $\alpha_{5} \beta_{1^{-}}$ integrin and $\mathrm{Ca}_{\mathrm{L}}$. The involvement of c-Src is supported by several findings in the present study: 1) co-IP of $\alpha_{1 \mathrm{C}}-\mathrm{Ca}_{\mathrm{L}}$ with $\mathrm{c}$-Src in arteriolar SM appears to be independent of $\mathrm{FN}$; 2) co-IP of $\alpha_{1 C^{-}-a_{L}}$ and phosphorylated c-Src is only observed in arteriolar SM incubated with FN; 3) co-IP of $\alpha_{1 \mathrm{C}}-\mathrm{Ca}_{\mathrm{L}}$ and c-Src is only observed upon adhesion of HEK293-T cells to $\mathrm{FN}$; and 4) mutation of the phosphorylation site for $\mathrm{c}-\mathrm{Src}$ in the $\mathrm{COOH}$ terminus in $\alpha_{1 \mathrm{C}}-\mathrm{Ca}_{\mathrm{L}}\left(\mathrm{Y}^{2122}\right)$ leads to reduced co-IP of $\alpha_{1 C}-\mathrm{Ca}_{\mathrm{L}}$ with $\beta_{1}$-integrin and of $\alpha_{1 \mathrm{C}}-\mathrm{Ca}_{\mathrm{L}}$ with c-Src. These results are consistent with previous findings that purified c-Src associates with the $\mathrm{COOH}$ terminus of $\alpha_{1 \mathrm{C}}-\mathrm{Ca}_{\mathrm{L}}(19,20)$ and that a basal level of $\mathrm{Ca}_{\mathrm{L}}$ current depends on c-Src activity in colonic smooth muscle (16). Our co-IP findings are also consistent with a previous functional study from our laboratory showing that the potentiation of $\mathrm{Ca}_{\mathrm{L}}$ current following $\alpha_{5} \beta_{1^{-}}$ integrin ligation is significantly reduced in $\mathrm{Y}^{2122} \mathrm{~F} \alpha_{1 \mathrm{C}}-\mathrm{Ca}_{\mathrm{L}}$ constructs (14). Thus, preventing this tyrosine residue from being phosphorylated not only reduces the overall phosphorylation of $\mathrm{Ca}_{\mathrm{L}}$ by exogenous c-Src, but also reduces the spatial interaction between $\alpha_{1 \mathrm{C}}-\mathrm{Ca}_{\mathrm{L}}$ and $\beta_{1}$-integrin and between $\alpha_{1 C}-C_{L}$ and endogenous c-Src, indicating that the interactions between $\alpha_{1 C}-\mathrm{Ca}_{\mathrm{L}}$ and $\beta_{1}$-integrin and between $\alpha_{1 \mathrm{C}}-\mathrm{Ca}_{\mathrm{L}}$ and 
c-Src are required for current potentiation following $\alpha_{5} \beta_{1^{-}}$ integrin ligation.

Our IP studies also identified a region in the $\alpha_{1 C^{-}}-\mathrm{Ca}_{\mathrm{L}} \mathrm{COOH}$ terminus containing two PRDs (P1/P2) as another potential binding domain for $\mathrm{c}-\mathrm{Src}$. Reduced associations between $\alpha_{1 \mathrm{C}^{-}}$ $\mathrm{Ca}_{\mathrm{L}}$ and $\beta_{1}$-integrin and between $\alpha_{1 \mathrm{C}}-\mathrm{Ca}_{\mathrm{L}}$ and $\mathrm{c}$-Src were observed in the $\Delta \mathrm{P} 1 / \Delta \mathrm{P} 2 \alpha_{1 C^{-}} \mathrm{Ca}_{\mathrm{L}}$ mutant. Our results agree with a previous study demonstrating that fusion proteins containing $\alpha_{1 C}$ PRDs mediate interactions with c-Src in SY5Y cells expressing the neuronal $\mathrm{Ca}_{\mathrm{L}}$ isoform upon IGF stimulation (1). Taken together, the results suggest multiple roles for PRDs in association with the macromolecular complex containing $\beta_{1}$-integrin, $\mathrm{c}-\mathrm{Src}$, and $\alpha_{1 \mathrm{C}}-\mathrm{Ca}_{\mathrm{L}}$.

FAK is another proline-rich tyrosine kinase known to provide a binding site for $\mathrm{SH} 2$ and $\mathrm{SH} 3$ domain-containing proteins such as paxillin, vinculin, talin, p130Cas, and Crk (42). Although we did not specifically examine whether $\alpha_{1 \mathrm{C}}-\mathrm{Ca}_{\mathrm{L}}$ associates with FAK, our previous studies in vascular SMC revealed that a significant amount of the $\mathrm{Ca}_{\mathrm{L}}$ current potentiation following $\alpha_{5} \beta_{1}$-integrin engagement was attenuated by dialysis of the cells with an antibody against FAK (40). A precedent for an association between FAK and another ion channel has been established by studies of Cherubini et al. (4), who demonstrated the association between FAK and the human ether-a-go-go-related gene (hERG) channel. In addition, PYK2, a family member of the FAK tyrosine kinases, was demonstrated to associate with cardiac $\alpha_{1 \mathrm{C}}-\mathrm{Ca}_{\mathrm{L}}$ via binding to PRDs (9). On the basis of the above, the PRDs in the $\alpha_{1 C}-\mathrm{Ca}_{\mathrm{L}}$ appear to play significant roles in the assembly of a macromolecular complex containing $\mathrm{Ca}_{\mathrm{L}}, \alpha_{5} \beta_{1}$-integrin, c-Src, and potentially other protein tyrosine kinases.

It should be noted that the roles of PRDs in the physical and functional association of $\alpha_{1 C}-\mathrm{Ca}_{\mathrm{L}}$ with $\alpha_{5} \beta_{1}$-integrin may be more complicated than at first suggested by the preceding discussion. When the $\Delta \mathrm{P} 1 / \Delta \mathrm{P} 2 \alpha_{1 \mathrm{C}}-\mathrm{Ca}_{\mathrm{L}}$ mutant is expressed, the IP results (Fig. 6, $A$ and $C$ ) reveal a reduced association between $\alpha_{1 C}-\mathrm{Ca}_{\mathrm{L}}$ and $\beta_{1}$-integrin and between $\alpha_{1 \mathrm{C}}-\mathrm{Ca}_{\mathrm{L}}$ and c-Src, compared with WT $\alpha_{1 \mathrm{C}}-\mathrm{Ca}_{\mathrm{L}}$, whereas the electrophysiological data (Fig. 7, $A$ and $B$ ) reveal no substantial impairment in the degree of $\mathrm{Ca}_{\mathrm{L}}$ current potentiation following $\alpha_{5} \beta_{1^{-}}$ integrin ligation. The discrepancy may arise from two issues. First, the PRD regions that we deleted from $\alpha_{1 C}-\mathrm{Ca}_{\mathrm{L}}$ lie within the distal $\mathrm{COOH}$ terminus inhibitory region (DCT). Two studies have shown that deletion of the homologous PRDs (aa 1966-2004) in the cardiac $\mathrm{Ca}_{\mathrm{L}}$ isoform leads to enhancement of basal $\mathrm{Ca}_{\mathrm{L}}$ current $(13,38)$. Deletion of the PRDs removes part of the DCT, which may partially relieve constitutive channel inhibition by the DCT segment, though this has not been specifically tested. However, the major differences between the neuronal, cardiac, and smooth muscle isoforms of the $\mathrm{Ca}_{\mathrm{L}}$ channel reside in the more distal regions of the respective $\mathrm{COOH}$ termini, and whether or not the DCT segment exerts strong inhibitory control of the neuronal $\mathrm{Ca}_{\mathrm{L}}$ has not been determined.

A second explanation for the discrepancy between the structural and functional PRD results is the possible contribution of another PRD that has been identified in the II-III linker region of $\alpha_{1 \mathrm{C}}-\mathrm{Ca}_{\mathrm{L}}$ (aa 857-861). A study by Dubuis et al. (9) suggests that the II-III linker region appears to play a role in extending the activation range of cardiac $\mathrm{Ca}_{\mathrm{L}}$, which consequently alters $\mathrm{Ca}_{\mathrm{L}}$ function. Our IP results revealed that deletion of the
$\mathrm{COOH}$-terminal PRDs only reduced c-Src coassociation with $\alpha_{1 C}-\mathrm{Ca}_{\mathrm{L}}$ by $42 \%$, even when the amount of truncated $\mathrm{COOH}-$ terminal $\alpha_{1 \mathrm{C}}-\mathrm{Ca}_{\mathrm{L}}$ mutants for IP was increased by twofold (Supplemental Fig. S2, $A$ and $C$ ). Thus, deletion of only the PRDs in the $\mathrm{COOH}$ terminus of $\alpha_{1 C^{-}} \mathrm{Ca}_{\mathrm{L}}$ may not be sufficient to fully abolish the potentiation in $\mathrm{Ca}_{\mathrm{L}}$ current following $\alpha_{5} \beta_{1}$-integrin engagement. Overall, our electrophysiological and IP results agree with the findings of Dubuis et al. and suggest the possibility of another important c-Src binding region in $\alpha_{1 C^{-}}-\mathrm{Ca}_{\mathrm{L}}$.

Reduced association between $\alpha_{1 C^{-}} C a_{L}$ and $\beta_{1}$-integrin is not due to faulty membrane targeting of $C a_{L}$. The amino acid residues $1623-1733$ in the $\mathrm{COOH}$ terminus of cardiac $\alpha_{1 \mathrm{C}}-\mathrm{Ca}_{\mathrm{L}}$ have been shown to mediate the membrane targeting of the channel (11). Using IF, we detected no significant difference in membrane targeting of $\alpha_{1 \mathrm{C}}-\mathrm{Ca}_{\mathrm{L}}$ or $\beta_{1}$-integrin in $\mathrm{S}^{1901} \mathrm{~A} /$ $\mathrm{Y}^{2122} \mathrm{~F}-\mathrm{Ca}$, truncated $\alpha_{1 \mathrm{C}}-\mathrm{Ca}_{\mathrm{L}}$ at amino acid residue 1862 , or $\Delta \mathrm{P} 1 / \Delta \mathrm{P} 2-\mathrm{Ca}_{\mathrm{L}}$, compared with WT-Ca $\mathrm{L}$. Our results suggest that the reduced association between $\alpha_{1 C^{-}}-\mathrm{Ca}_{\mathrm{L}}$ and $\beta_{1}$-integrin observed in the above mentioned $\alpha_{1 \mathrm{C}}-\mathrm{Ca}_{\mathrm{L}}$ mutants is not due to unsuccessful membrane targeting of $\alpha_{1 C}-\mathrm{Ca}_{\mathrm{L}}$. Our findings agree with those of Gao et al. (11) that the regions in the $\mathrm{COOH}$ terminus required for successful membrane targeting of cardiac $\mathrm{Ca}_{\mathrm{L}}$ are amino acid residues 1623-1733. Because those specific regions are not altered in our mutant $\alpha_{1 \mathrm{C}}-\mathrm{Ca}_{\mathrm{L}}$ constructs, the reduced association between $\alpha_{1 C^{-}} \mathrm{Ca}_{\mathrm{L}}$ and $\beta_{1^{-}}$ integrin in our mutant constructs are unlikely attributable to incorrect membrane targeting of $\mathrm{Ca}_{\mathrm{L}}$. In addition, our IF results also suggest that the association between $\alpha_{1 C^{-}} \mathrm{Ca}_{\mathrm{L}}$ and $\beta_{1^{-}}$ integrin on the plasma membrane is independent of the PKA/ c-Src phosphorylation sites, the PRD domains, or the distal $\mathrm{COOH}$ terminus after amino acid residue 1862 in $\alpha_{1 \mathrm{C}}-\mathrm{Ca}_{\mathrm{L}}$. These results suggest that $\alpha_{5} \beta_{1}$-integrin modulates $\mathrm{Ca}_{\mathrm{L}}$ function independent of the interactions of the two proteins on the plasma membrane. The IF results agree with the IP and patch-clamp findings in that the formation of a macromolecular complex including PKA, c-Src, $\alpha_{5} \beta_{1}$-integrin, and $\mathrm{Ca}_{\mathrm{L}}$ in the cytoplasm following $\alpha_{5} \beta_{1}$-integrin engagement appears to play an important role in $\mathrm{Ca}_{L}$ current potentiation by $\alpha_{5} \beta_{1}$-integrin.

Physiological significance of $\mathrm{Ca}_{L}$ association with integrin. Our findings of an association between $\mathrm{Ca}_{L}$ and $\beta_{1}$-integrin and between $\mathrm{Ca}_{L}$ and $\mathrm{c}-\mathrm{Src}$ provide evidence for a macromolecular signaling complex composed of $\alpha_{5} \beta_{1}$-integrin, $\mathrm{Ca}_{\mathrm{L}}, \mathrm{c}-\mathrm{Src}$, PKA, and possibly other focal adhesion components. Formation of this complex appears to be important for regulation of $\mathrm{Ca}_{\mathrm{L}}$ function following integrin-ECM interaction. Our IP results are consistent with previous findings that $\mathrm{c}-\mathrm{Src}$ is involved in the increase of $\mathrm{Ca}_{\mathrm{L}}$ current potentiation in response to PDGF (17) or IGF (1) and with the finding that a c-Src-FAK complex forms in colonic smooth muscle in response to PDGF stimulation (16). Interestingly, cross talk between integrins and growth factors has been demonstrated in several studies, with the interaction of FAK and c-Src as a point of convergence (10, $28,35)$. Although it is not known whether these two signaling pathways converge to regulate an ion channel, an intriguing possibility is that PDGF or IGF act in conjunction with $\alpha_{5} \beta_{1^{-}}$ integrin to produce additive or synergistic potentiation of $\mathrm{Ca}_{\mathrm{L}}$ function by integrin.

In summary, this is the first study to provide evidence for the association of $\alpha_{1 C}-C_{L}$ with $\alpha_{5} \beta_{1}$-integrin or $\alpha_{1 C}-C_{L}$ with c-Src in arteriolar smooth muscle. This association depends on 
engagement of $\alpha_{5} \beta_{1}$-integrin by FN and specific regions in the $\alpha_{1 \mathrm{C}}-\mathrm{Ca}_{\mathrm{L}} \mathrm{COOH}$ terminus, including two phosphorylation sites for PKA and c-Src and proline-rich domains that provide a binding motif for $\mathrm{SH} 3$ domain-containing proteins, such as c-Src. Identification of these regions, along with our electrophysiological findings, suggests that a macromolecular complex is assembled upon engagement of $\alpha_{5} \beta_{1}$-integrin and that the interactions of proteins within this complex contribute to modulation of $\mathrm{Ca}_{\mathrm{L}}$ function. Our study provides new insights into a $\mathrm{Ca}_{\mathrm{L}}$ macromolecular regulatory complex that is required for functional regulation of the channel following $\alpha_{5} \beta_{1}$-integrin engagement.

\section{ACKNOWLEDGMENTS}

The authors acknowledge the technical assistance of Judy Davidson, Cara Froyd, Steve Dorman, and Shan-Yu Ho in preparing cell cultures and performing transfections. The technical assistance of Zhaohui Li, Dr. Luke Sun, and Dr. Luis Martinez-Lemus with the initial use of the confocal microscope is greatly appreciated. Rat neuronal WT $\alpha_{1 \mathrm{C}}, \beta_{1 \mathrm{~b}}$, and $\alpha_{2} \delta$ DNA, subcloned into pcDNA3.1 vectors, were gifts from Dr. T. Snutch.

\section{GRANTS}

This project was funded by National Institutes of Health Grants HL071796, HL-072989, and P01 HL-095486 (to M. J. Davis). G. W. Zamponi holds funding from the Heart and Stroke Foundation and is a Canada Research Chair and Alberta Heritage Foundation for Medical Research Scientist.

\section{DISCLOSURES}

No conflicts of interest, financial or otherwise, are declared by the author(s).

\section{REFERENCES}

1. Bence-Hanulec KK, Marshall J, Blair LA. Potentiation of neuronal L calcium channels by IGF-1 requires phosphorylation of the alpha1 subunit on a specific tyrosine residue. Neuron 27: 121-131, 2000.

2. Callaghan B, Koh SD, Keef KD. Muscarinic M2 receptor stimulation of Cav1.2b requires phosphatidylinositol 3-kinase, protein kinase $\mathrm{C}$, and c-Src. Circ Res 94: 626-633, 2004.

3. Callaghan B, Zhong J, Keef KD. Signaling pathway underlying stimulation of L-type $\mathrm{Ca}^{2+}$ channels in rabbit portal vein myocytes by recombinant G $\beta \gamma$-subunits. Am J Physiol Heart Circ Physiol 291: H2541H2546, 2006.

4. Cherubini A, Hofmann G, Pillozzi S, Guasti L, Crociani O, Cilia E, Di Stefano P, Degani S, Balzi M, Olivotto M, Wanke E, Becchetti A, Defilippi P, Wymore R, Arcangeli A. Human ether-a-go-go-related gene 1 channels are physically linked to beta1 integrins and modulate adhesiondependent signaling. Mol Biol Cell 16: 2972-2983, 2005.

5. Dai S, Hall DD, Hell JW. Supramolecular assemblies and localized regulation of voltage-gated ion channels. Physiol Rev 89: 411-452, 2009.

6. Davare MA, Avdonin V, Hall DD, Peden EM, Burette A, Weinberg RJ, Horne MC, Hoshi T, Hell JW. A beta2 adrenergic receptor signaling complex assembled with the Ca2+ channel Cav1.2. Science 293: 98-101, 2001.

7. Davis GE, Bayless KJ, Davis MJ, Meininger GA. Regulation of tissue injury responses by the exposure of matricryptic sites within extracellular matrix molecules. Am J Pathol 156: 1489-1498, 2000.

8. Davis MJ, Wu X, Nurkiewicz TR, Kawasaki J, Davis GE, Hill MA, Meininger GA. Integrins and mechanotransduction of the vascular myogenic response. Am J Physiol Heart Circ Physiol 280: H1427-H1433, 2001.

9. Dubuis E, Rockliffe N, Hussain M, Boyett M, Wray D, Gawler D. Evidence for multiple Src binding sites on the alpha1c L-type $\mathrm{Ca}^{2+}$ channel and their roles in activity regulation. Cardiovasc Res 69: 391-401, 2006.

10. Eliceiri BP. Integrin and growth factor receptor crosstalk. Circ Res 89: 1104-1110, 2001

11. Gao T, Bunemann M, Gerhardstein BL, Ma H, Hosey MM. Role of the $\mathrm{C}$ terminus of the alpha $1 \mathrm{C}(\mathrm{CaV} 1.2)$ subunit in membrane targeting of cardiac L-type calcium channels. J Biol Chem 275: 25436-25444, 2000.
12. Gao T, Cuadra AE, Ma H, Bunemann M, Gerhardstein BL, Cheng T, Eick RT, Hosey MM. C-terminal fragments of the alpha 1C (CaV1.2) subunit associate with and regulate L-type calcium channels containing C-terminal-truncated alpha 1C subunits. J Biol Chem 276: 21089-21097, 2001.

13. Gerhardstein BL, Gao T, Bunemann M, Puri TS, Adair A, Ma H, Hosey MM. Proteolytic processing of the $C$ terminus of the alpha(1C) subunit of L-type calcium channels and the role of a proline-rich domain in membrane tethering of proteolytic fragments. J Biol Chem 275: 8556$8563,2000$.

14. Gui P, Wu X, Ling S, Stotz SC, Winkfein RJ, Wilson E, Davis GE, Braun AP, Zamponi GW, Davis MJ. Integrin receptor activation triggers converging regulation of Cav1.2 calcium channels by c-Src and protein kinase A pathways. J Biol Chem 281: 14015-14025, 2006.

15. Howe AK. Regulation of actin-based cell migration by cAMP/PKA. Biochim Biophys Acta 1692: 159-174, 2004.

16. Hu XQ, Singh N, Mukhopadhyay D, Akbarali HI. Modulation of voltage-dependent $\mathrm{Ca}^{2+}$ channels in rabbit colonic smooth muscle cells by c-Src and focal adhesion kinase. J Biol Chem 273: 5337-5342, 1998.

17. Hughes AD. Increase in tone and intracellular $\mathrm{Ca}^{2+}$ in rabbit isolated ear artery by platelet-derived growth factor. Br J Pharmacol 114: 138-142, 1995.

18. Huveneers S, Danen EH. Adhesion signaling - crosstalk between integrins, Src and Rho. J Cell Sci 122: 1059-1069, 2009.

19. Jin X, Morsy N, Shoeb F, Zavzavadjian J, Akbarali HI. Coupling of M2 muscarinic receptor to L-type Ca channel via c-src kinase in rabbit colonic circular smooth muscle. Gastroenterology 123: 827-834, 2002.

20. Kang M, Ross GR, Akbarali HI. COOH-terminal association of human smooth muscle calcium channel Cav1.2b with Src kinase protein binding domains: effect of nitrotyrosylation. Am J Physiol Cell Physiol 293: C1983-C1990, 2007.

21. Kuo L, Chilian WM, Davis MJ. Interaction of pressure- and flowinduced responses in porcine coronary resistance vessels. Am J Physiol Heart Circ Physiol 261: H1706-H1715, 1991.

22. Langton PD. Calcium channel currents recorded from isolated myocytes of rat basilar artery are stretch sensitive. J Physiol 471: 1-11, 1993.

23. Lehoux S, Tedgui A. Signal transduction of mechanical stresses in the vascular wall. Hypertension 32: 338-345, 1998.

24. Li Q, Lau A, Morris TJ, Guo L, Fordyce CB, Stanley EF. A syntaxin 1, Galpha(o), and N-type calcium channel complex at a presynaptic nerve terminal: analysis by quantitative immunocolocalization. $J$ Neurosci 24 : 4070-4081, 2004.

25. Li YS, Haga JH, Chien S. Molecular basis of the effects of shear stress on vascular endothelial cells. J Biomech 38: 1949-1971, 2005.

26. Lim CJ, Kain KH, Tkachenko E, Goldfinger LE, Gutierrez E, Allen MD, Groisman A, Zhang J, Ginsberg MH. Integrin-mediated protein kinase A activation at the leading edge of migrating cells. Mol Biol Cell 19: 4930-4941, 2008.

27. Ling S, Sheng JZ, Braun JE, Braun AP. Syntaxin 1A co-associates with native rat brain and cloned large conductance, calcium-activated potassium channels in situ. J Physiol 553: 65-81, 2003.

28. Maile LA, Badley-Clarke J, Clemmons DR. The association between integrin-associated protein and SHPS-1 regulates insulin-like growth factor-I receptor signaling in vascular smooth muscle cells. Mol Biol Cell 14: 3519-3528, 2003.

29. Martinez-Lemus LA, Crow T, Davis MJ, Meininger GA. alphavbeta3and alpha5beta1-integrin blockade inhibits myogenic constriction of skeletal muscle resistance arterioles. Am J Physiol Heart Circ Physiol 289: H322-H329, 2005.

30. Matthews BD, Overby DR, Mannix R, Ingber DE. Cellular adaptation to mechanical stress: role of integrins, Rho, cytoskeletal tension and mechanosensitive ion channels. J Cell Sci 119: 508-518, 2006.

31. McPhee JC, Dang YL, Davidson N, Lester HA. Evidence for a functional interaction between integrins and $\mathrm{G}$ protein-activated inward rectifier $\mathrm{K}^{+}$channels. J Biol Chem 273: 34696-34702, 1998.

32. Meyer CJ, Alenghat FJ, Rim P, Fong JH, Fabry B, Ingber DE. Mechanical control of cyclic AMP signalling and gene transcription through integrins. Nat Cell Biol 2: 666-668, 2000.

33. Mies F, Spriet C, Heliot L, Sariban-Sohraby S. Epithelial $\mathrm{Na}^{+}$channel stimulation by $\mathrm{n}-3$ fatty acids requires proximity to a membrane-bound A-kinase-anchoring protein complexed with protein kinase A and phosphodiesterase. J Biol Chem 282: 18339-18347, 2007.

34. Nguyen JT, Lim WA. How Src exercises self-restraint. Nat Struct Biol 4: 256-260, 1997. 
35. Plopper GE, McNamee HP, Dike LE, Bojanowski K, Ingber DE. Convergence of integrin and growth factor receptor signaling pathways within the focal adhesion complex. Mol Biol Cell 6: 1349-1365, 1995.

36. Puklin-Faucher E, Sheetz MP. The mechanical integrin cycle. J Cell Sci 122: 179-186, 2009.

37. Turner CE, Glenney JR Jr, Burridge K. Paxillin: a new vinculin-binding protein present in focal adhesions. J Cell Biol 111: 1059-1068, 1990.

38. Wei X, Neely A, Lacerda AE, Olcese R, Stefani E, Perez-Reyes E, Birnbaumer L. Modification of $\mathrm{Ca}^{2+}$ channel activity by deletions at the carboxyl terminus of the cardiac alpha 1 subunit. J Biol Chem 269: 1635-1640, 1994.
39. Wijetunge S, Hughes AD. Src family tyrosine kinases mediate contraction of rat isolated tail arteries in response to a hyposmotic stimulus. $J$ Hypertens 25: 1871-1878, 2007.

40. Wu X, Davis GE, Meininger GA, Wilson E, Davis MJ. Regulation of the L-type calcium channel by alpha 5beta 1 integrin requires signaling between focal adhesion proteins. J Biol Chem 276: 30285-30292, 2001.

41. Wu X, Mogford JE, Platts SH, Davis GE, Meininger GA, Davis MJ. Modulation of calcium current in arteriolar smooth muscle by alphav beta3 and alpha5 beta1 integrin ligands. J Cell Biol 143: 241-252, 1998.

42. Zaidel-Bar R, Itzkovitz S, Ma'ayan A, Iyengar R, Geiger B. Functional atlas of the integrin adhesome. Nat Cell Biol 9: 858-867, 2007.

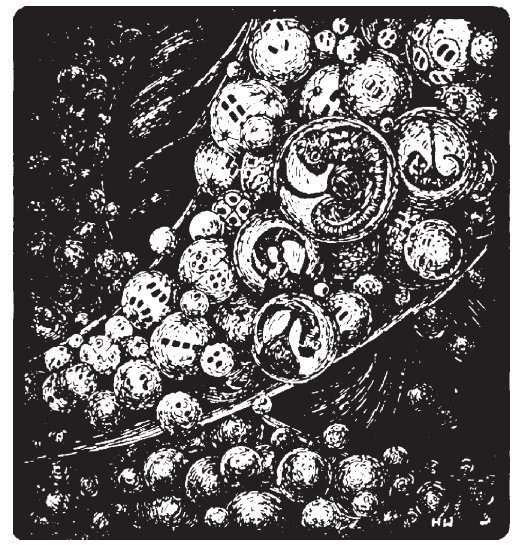

